\title{
Investigation of solid oxide fuel cell operation with synthetic biomass gasification product gases as a basis for enhancing its performance
}

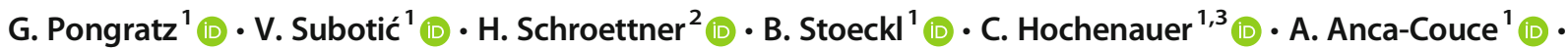 \\ R. Scharler ${ }^{1,3}$
}

Received: 16 January 2020 / Revised: 31 March 2020 / Accepted: 2 April 2020 / Published online: 16 April 2020

(C) The Author(s) 2020, corrected publication 2020

\begin{abstract}
Solid oxide fuel cells represent a promising technology to increase the electrical efficiency of biomass-based combined-heat-power systems in comparison to state-of-the-art gas engines, additionally providing high temperature heat. To identify favorable fuel gas compositions for an efficient coupling with gasifiers at low degradation risk is of major importance to ensure stability, reliability, and durability of the systems used, thus increasing attractiveness of electricity production from biomass. Therefore, this study presents a comprehensive analysis on the influence of main gas components from biomass gasification on the performance and efficiency of a cell relevant for real application. An industrial-size electrolyte supported single cell with nickel/gadolinium-doped ceria anode was selected showing high potential for gasifier-solid oxide fuel cell systems. Beneficial gas component ratios enhancing the power output and electric efficiency are proposed based on the experimental study performed. Furthermore, the degradation stability of a SOFC fueled with a synthetic product gas representing steam gasification of woody biomass was investigated. After $500 \mathrm{~h}$ of operation under load at a steam-to-carbon ratio of 2.25 in the fuel gas, no performance or anode degradation could be detected.
\end{abstract}

Keywords Solid oxide fuel cell (SOFC) · Biomass gasification · Electrochemical impedance spectroscopy (EIS) analysis · Degradation study

\section{Introduction}

Gasifiers coupled with gas engines increasingly replace steam turbine cycles as state-of-the-art systems for converting solid biomass to power because they provide higher

\section{Highlights}

- Review on SOFC configurations suitable for the coupling with biomass gasifiers.

- Comprehensive electrochemical cell characterization for varying $\mathrm{H}_{2} \mathrm{O}$,

$\mathrm{CO}, \mathrm{CH}_{4}$, and $\mathrm{CO}_{2}$ compounds.

- Degradation experiment with steam-rich gasifier product gas considering nickel re-oxidation.

G. Pongratz

gernot.pongratz@tugraz.at

1 Institute of Thermal Engineering, Graz University of Technology, Inffeldgasse 21, 8010 Graz, Austria

2 Institute for Electron Microscopy and Nanoanalysis, Graz University of Technology, Steyrergasse 17, 8010 Graz, Austria

3 BEST - Bioenergy and Sustainable Technologies GmbH, Inffeldgasse 21b, 8010 Graz, Austria thermodynamic efficiencies, especially for small- to medium-scale plants. However, also in this case, the electrical efficiency is limited by the thermodynamic cycle. Combined with high biomass feedstock costs, this reduces the attractiveness of electricity production from biomass. Coupling gasifiers with high temperature solid oxide fuel cells (SOFCs) instead of gas engines would increase the electrical efficiency from around $25-30 \%$ to values up to over $40 \%$. Additionally, high temperature heat can be provided thus increasing the attractiveness of power production from solid biomass [1,2].

As SOFCs are based on heterogeneous catalytic reaction processes, the main drawback of their use with gasifiers in comparison to combustion engines is the higher sensitivity to degradation of the catalytic-active surface, which decreases power output or can even lead to a failure [3]. Degradation can be caused by components of the derived product gas. Impurities like tars, dust, sulfur and chlorine compounds that can either act as catalyst poison or lead to depositions in the porous fuel electrode, both deteriorating SOFC performance and changing its microstructure [4-8]. SOFC operating conditions like temperature, electrical load, but especially the concentration of the main components of the employed fuel gas 
can also induce fuel electrode degradation, e.g., a low steamto-carbon-ratio (SCR) (see Eq. (1) as proposed in [9]), can lead to carbon depositions within the anode layer and a high steam concentration to the re-oxidation of the nickel catalyst used in state-of-the-art SOFC anodes [10, 11].

$\mathrm{SCR}=\frac{\mathrm{H}_{2} \mathrm{O}}{\mathrm{CO}+\mathrm{CH}_{4}}$

Thus, identifying favorable gas compositions, impurity thresholds, and SOFC operating conditions avoiding cell degradation is of major importance to ensure stability, reliability, and durability of the systems used [12]. This paper focuses on the influence of main gas components of biomass gasification product gases on the performance of a SOFC. The experimental method, cell configuration used as well as operating conditions for the conducted experiments were defined on basis of a comprehensive literature review on promising configurations for the coupling of SOFCs with biomass gasifiers.

\subsection{SOFC operation with gas components from a product gas: a review}

Several studies have already been published investigating the influence of the main gas components from biomass gasifiers $\left(\mathrm{H}_{2} \mathrm{O}, \mathrm{H}_{2}, \mathrm{CO}, \mathrm{CO}_{2}, \mathrm{CH}_{4}\right)$ on SOFC characteristics: It is argued in [13] that when feeding an anode-supported cell (ASC) with nickel/yttria-stabilized zirconia (Ni/YSZ) anode and $25 \mathrm{~cm}^{2}$ active surface with $\mathrm{CO} / \mathrm{H}_{2}$ mixtures, a significant performance decrease is observed at high $\mathrm{CO}$ fractions $(>90$ vol\%). The results of a detailed electrochemical characterization of a Ni/YSZ ASC with $25 \mathrm{~cm}^{2}$ active surface over a broad measuring range of temperature and $\mathrm{H}_{2}-\mathrm{CO}-\mathrm{CO}_{2}-\mathrm{N}_{2}-$ $\mathrm{H}_{2} \mathrm{O}$ fuel gas mixtures is presented in [14]. The authors claim that only $\mathrm{H}_{2}$ is assumed to be directly electrochemically oxidized in a Ni/YSZ SOFC. CO in wet fuel gas mixtures predominantly reacts with $\mathrm{H}_{2} \mathrm{O}$ to form $\mathrm{H}_{2}$ and $\mathrm{CO}_{2}$ via the water gas shift (WGS) reaction (see Eq. (2) with $\Delta_{\mathrm{R}} \mathrm{H}_{\mathrm{m}}{ }^{0}$ as the standard enthalpy of reaction).

$$
\begin{aligned}
& \mathrm{CO}+\mathrm{H}_{2} \mathrm{O} \Leftrightarrow \mathrm{CO}_{2}+\mathrm{H}_{2} \\
& \Delta_{R} H_{m}{ }^{2}=-41.1 \mathrm{~kJ} / \mathrm{mol}
\end{aligned}
$$

The opposite is claimed by the authors of [15]. In their work, the impact of $\mathrm{CO}$ and $\mathrm{CO}_{2}$ on the performance of a $\mathrm{Ni} / Y S Z$ ASC with $10 \mathrm{~cm}^{2}$ active surface is investigated with the outcome that the electrochemical reactivity of $\mathrm{CO}$ in a $\mathrm{CO} /$ $\mathrm{N}_{2}$ mixture is comparable to the reactivity of $\mathrm{H}_{2}$ in a $\mathrm{H}_{2} / \mathrm{N}_{2}$ mixture as long as the $\mathrm{CO}$ content does not exceed $27 \mathrm{vol} \%$. For $\mathrm{CO}$ concentrations above $27 \mathrm{vol} \%$, the higher diffusion resistance of $\mathrm{CO}$ in comparison to $\mathrm{H}_{2}$ is claimed as reason for increasing performance losses. A lower oxidation rate of $\mathrm{CO}$ in comparison to $\mathrm{H}_{2}$ is also stated in [16]. The electrochemical reactivity of $\mathrm{CO}$ in mixtures with $\mathrm{H}_{2}$ as second fuel component can also be demonstrated in zero and higher dimensional models. In [17], the authors claim more accurate results when considering electrochemical $\mathrm{CO}$ oxidation in their SOFC model in comparison to studies only considering CO in WGS reactions $[18,19]$. Hence, CO oxidation in SOFCs cannot be neglected. In [20], the impact of biosyngas and its components on the anode of a nickel/ gadolinium-doped ceria (Ni/GDC) electrolyte-supported cell (ESC) is investigated. The authors state that increasing amounts of $\mathrm{N}_{2}$ and $\mathrm{CO}$ in dry $\mathrm{H}_{2}$ lead to higher diffusion related losses, hence decreasing cell performance. Moreover, they point out that the addition of $\mathrm{CO}_{2}$ to dry $\mathrm{H}_{2}$ leads to the production of $\mathrm{H}_{2} \mathrm{O}$ according to the water gas shift (see Eq. (2)). $\mathrm{As}_{2} \mathrm{O}$ is the product of the hydrogen oxidation reaction (see Eq. (3)), even small amounts of water decrease the voltage losses at low electrical loads, also known as activation polarization [21]. A decreasing activation polarization results in a linearization of the current-voltage correlation (polarization curve), which is clearly visible in the operating range of low current densities. The impact of fuel starvation, which causes concentration losses, is visible at high current densities, as theoretically described in [21] and experimentally approved in [22]. Hence, a linear current-voltage correlation results in a more stable operation behavior due to better controllability of the cell.

$$
\begin{gathered}
\mathrm{H}_{2}+0.5 \mathrm{O}_{2} \Rightarrow \mathrm{H}_{2} \mathrm{O} \\
\Delta_{R} H_{m}{ }^{0}=-242 \mathrm{~kJ} / \mathrm{mol}
\end{gathered}
$$

In [23], it is also highlighted that a higher performance for the oxidation of $\mathrm{H}_{2}$ than of $\mathrm{CO}$ can be achieved in Ni/YSZ anodes. Moreover, the importance of the WGS reaction was highlighted, as in $\mathrm{H}_{2}-\mathrm{CO}$ mixtures the produced $\mathrm{H}_{2} \mathrm{O}$ (see Eq. (3)) reacts with $\mathrm{CO}$ to form $\mathrm{H}_{2}$ and $\mathrm{CO}_{2}$ as long as the $\mathrm{H}_{2}$ content is higher than ca. $50 \mathrm{vol} \%$. However, determining the rate of $\mathrm{H}_{2}$ production from $\mathrm{H}_{2} \mathrm{O}$ and $\mathrm{CO}$ via WGS is not trivial. As discussed in [24], SOFC operating conditions like gas velocity in the fuel flow field have a major influence on the kinetics of reactions occurring in the anode. Thus, the gas composition significantly varies as a function of the cell length, and it can strongly differ from the equilibrium composition defined by thermodynamic parameters. In addition, if the operating environment is favorable for carbon depositions, the gas composition will additionally change. In [25], the cell performance as well as polarization losses of a Ni/YSZ ASC with $81 \mathrm{~cm}^{2}$ active surface was investigated when using $\mathrm{CO} /$ $\mathrm{CO}_{2} / \mathrm{N}_{2}$ and $\mathrm{H}_{2} / \mathrm{H}_{2} \mathrm{O} / \mathrm{N}_{2}$ mixtures as fuel, showing lower performance levels of the cells when using $\mathrm{CO}$ as fuel. Analyses of electrochemical impedance spectroscopy (EIS) measurements identified performance losses as a result of higher activation polarization and diffusion losses in comparison to experiments using $\mathrm{H}_{2}$ as fuel [26, 27]. The most comprehensive study on the influence of varying syngas mixtures containing 
$\mathrm{H}_{2}, \mathrm{H}_{2} \mathrm{O}, \mathrm{CO}, \mathrm{CO}_{2}, \mathrm{CH}_{4}$, and $\mathrm{N}_{2}$ on the current-voltage correlation of an anode supported button cell with $\mathrm{Ni} / \mathrm{YSZ}$ anode was conducted by [28]. In that study, dilution effects as well as the influence of the fuel concentration on the cell characteristics were experimentally determined. Results were used to develop a black box model of the cell able to predict the current-voltage correlation and area specific resistance (ASR) based on the fuel composition, however, without identifying the specific loss mechanisms.

Based on the outcomes of the presented studies, the literature review depicts that (i) $\mathrm{H}_{2}$ is a more preferable oxidant than $\mathrm{CO}$ due to better diffusivity and electrochemical reactivity and (ii) dilution with $\mathrm{N}_{2}$ and $\mathrm{CO}_{2}$ should be minimized to avoid an increase of diffusion losses for all reactive gas components to the active centers of the cermet. Moreover, the importance of the WGS reaction was highlighted as $\mathrm{CO}_{2}$ would shift the water gas equilibrium to a side where more $\mathrm{CO}$ than $\mathrm{H}_{2}$ will be formed, thus increasing losses due to lower electrochemical activity of $\mathrm{CO}$ in comparison to $\mathrm{H}_{2}$. However, in dry $\mathrm{H}_{2}-\mathrm{CO}_{2}$ mixtures, $\mathrm{H}_{2} \mathrm{O}$ can be formed via the WGS reaction reducing activation polarization, thus linearizing the current-voltage correlation of a SOFC in the low load range. Nevertheless, a study on the influence of $\mathrm{H}_{2}, \mathrm{H}_{2} \mathrm{O}$, $\mathrm{CO}, \mathrm{CO}_{2}, \mathrm{CH}_{4}$, and $\mathrm{N}_{2}$ on the characteristics of a cell relevant for industrial applications is missing in literature. Cell types with potential for commercial use will therefore be discussed further on.

\subsection{Coupling gasifiers with SOFCs: promising configurations for single-cell testing}

The cell type, operating conditions, and fuel gas compositions for the experimental investigations presented in this paper were selected on basis of the reviewed studies to ensure relevance for industrial applications.

\subsubsection{Anode material}

The literature review showed that in general cells with $\mathrm{Ni} / \mathrm{GDC}$ or Ni/YSZ based anode have been experimentally studied in the past for the use with product gases relevant for biomass gasification. However, significantly more publications deal with cells based on Ni/YSZ anodes, possibly due to their better performance in electrochemically oxidizing hydrogen and being closer to a broad commercialization as claimed in $[10,28]$. But, as comprehensively reviewed in $[4,29,30]$, cells with $\mathrm{Ni} /$ GDC anode show a higher potential for the use with product gases from biomass gasification due to their higher tolerance against contaminants like $\mathrm{H}_{2} \mathrm{~S}, \mathrm{HCl}$ and tars in comparison to cells with $\mathrm{Ni} / \mathrm{YSZ}$ anode. Moreover, this anode material is less prone to the formation of solid carbon deposits when fueled with carbonaceous gases, especially at a low SCR [31]. Thus, cells with Ni/GDC anode were used for the experiments presented in this paper, especially considering future experiments with fuel gases containing contaminants as well as real product gases from biomass gasifiers.

\subsubsection{Cell design}

Moreover, the differences in the structure of the layers between an ESC and an ASC were considered to choose a design beneficial for the use with bio-syngases. Figure 1 shows the cross-sections of a typical ESC and ASC. Anode degradation by the means of solid carbon depositions within the porous structure or the volume-enhancing re-oxidation of the anodic nickel compounds can lead to cracks in the anode layer [11]. This has to be considered when cells are operated in environments favoring carbon deposition or nickel re-oxidation, both possible when using product gases from biomass gasification. In an ASC, most of the mechanical support is applied by the anodic layer in contrast to an ESC. Thus, the risk for gas leakages from the cathode to the anode side through cracks and therefore cell malfunction induced by anode degradation might be higher for ASCs than for ESCs. However, further research is necessary to substantiate this assumption.

To increase the relevance of test results for industrial applications, the use of cells with an active surface of at least $80 \mathrm{~cm}^{2}$ is beneficial. Hence, macroscopic effects occurring in industrial systems like uneven gas and temperature distribution as well as fuel utilization can be reproduced more easily [32]. Considering the proximity to industrial applications and the possibly lower risk of a functional failure, an ESC with $80 \mathrm{~cm}^{2}$ active surface was used for the experiments presented in this paper. Finally, gas compositions relevant for the coupling of SOFCs with biomass gasifiers are discussed to increase the usefulness of the experimental results presented further on.
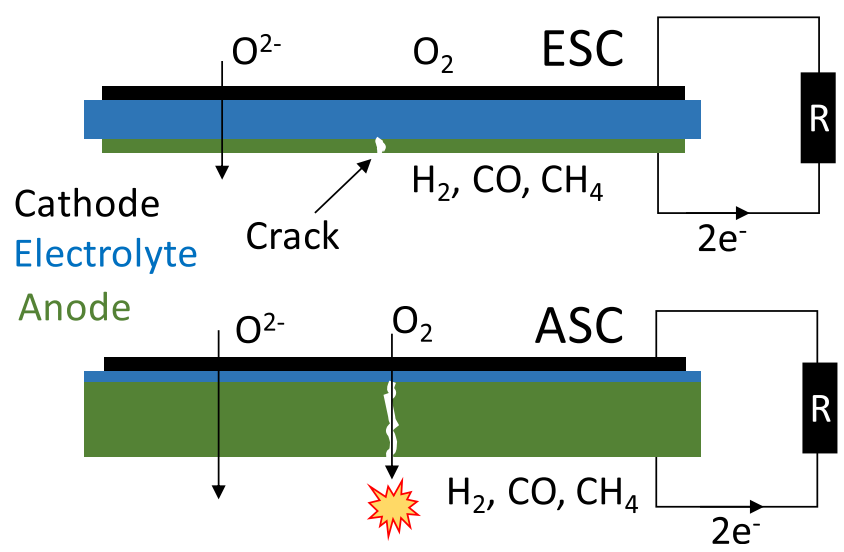

Fig. 1 Comparison of the malfunction risk induced by cracks in the anode layer for ESC (top) and ASC (bottom) SOFC structures 


\subsubsection{Gasifier, gasification agent, and gas cleaning}

When considering gasifier technologies, there are big differences in the product gases obtained. The main gas composition strongly depends on the reactor design as well as feedstock and gasification agent. Operating parameters are mainly used for fine tuning of the gas compositions. Table 1 shows examples of typical product gas compositions from common gasifier designs, being LHV the lower heating value. Fixed-bed downdraft gasifier with air (FDA) and a fluidized bed gasifier with steam (FBS) gasification agent are the most common gasification technologies. Both show a high potential for the coupling with SOFCs as discussed in [3, 33] but differ significantly in their product gas composition due to their diverse gasification agents.

To find out the most promising gas compositions for the experimental investigations, following issues were considered: The higher $\mathrm{H}_{2} / \mathrm{CO}$ ratio of the FBS gasifier in comparison to the FDA gasifier and the before mentioned better reactivity of $\mathrm{H}_{2}$ in comparison to $\mathrm{CO}$ might lead to a better overall cell performance. Moreover, the significantly lower $\mathrm{N}_{2}$ content is supposed to result in a lower diffusion resistivity of the reactants to the anode.

In [37], the authors prove via a thermodynamic model approach that the maximum net electrical efficiency of a biomass gasifier-SOFC power system can be reached using steam as gasification agent.

The risk for carbon depositions increases with decreasing $\mathrm{SCR}$ as one of the main deposition preventing mechanisms is the reaction of carbon with steam to form $\mathrm{H}_{2}$ and $\mathrm{CO}$ as shown in Eq. (4) [32, 38]. Therefore, the usage of product gases from steam blown gasifiers seems more suitable for a carbon deposition free operation of SOFCs.

$$
\begin{gathered}
\mathrm{C}+\mathrm{H}_{2} \mathrm{O} \Leftrightarrow \mathrm{H}_{2}+\mathrm{CO} \\
\Delta_{R} H_{m}{ }^{0}=+131 \mathrm{~kJ} / \mathrm{mol}
\end{gathered}
$$

\begin{tabular}{llcl}
\cline { 2 - 4 } $\begin{array}{l}\text { Table 1 Product gas } \\
\text { compositions of } \\
\text { common biomass } \\
\text { gasifier designs (values }\end{array}$ & vol\% w.b. & FDA & FBS \\
\cline { 2 - 4 } based on [34-36] and & $\mathrm{H}_{2}$ & 16 & 24 \\
internal data) & $\mathrm{H}_{2} \mathrm{O}$ & 15 & 37 \\
& $\mathrm{CO}$ & 17 & 15 \\
& $\mathrm{CO}_{2}$ & 13 & 13 \\
& $\mathrm{CH}_{4}$ & 3 & 7 \\
& $\mathrm{~N}_{2}$ & 36 & 4 \\
& $\mathrm{SCR}$ & 0.75 & 1.68 \\
& $\mathrm{H}_{2} / \mathrm{CO}$ & 0.94 & 1.6 \\
& $\mathrm{H}_{2} \mathrm{O} / \mathrm{CH}_{4}$ & 5 & 5.29 \\
& $\mathrm{LHV}\left[\mathrm{MJ} / \mathrm{Nm}^{3}\right.$ w.b.] & 4.99 & 7.05 \\
\hline
\end{tabular}

However, the SCR for the FBS and FDA gas composition presented in Table 1 decreases when the mixtures reach thermodynamic equilibrium at temperatures relevant for SOFCs $\left(600-850{ }^{\circ} \mathrm{C}\right)$. Nevertheless, the molar ratio of carbon, oxygen, and hydrogen atoms does not change. By considering solid carbon in the thermodynamic equilibrium calculations using the Gibbs energy minimization method, carbon forming boundaries can be calculated as demonstrated in [39]. These boundaries for temperatures relevant for SOFC operation are shown in Fig. 2. However, these thermodynamic equilibrium calculations provide only an indication of the carbon deposition risk. Kinetic effects of reactions occurring in the anode play a major role in the formation of solid carbon as highlighted in $[24,40]$. This was experimentally proved in [33] for a FDA gas mixture similar to the one presented in Table 1: Carbon depositions were detected after operating a Ni/YSZ ASC at $750{ }^{\circ} \mathrm{C}$ for $120 \mathrm{~h}$, although thermodynamically not possible according to Fig. 2. Nevertheless, the SCR increases with increasing load as $\mathrm{H}_{2} \mathrm{O}$ is formed in the electrochemical oxidation of $\mathrm{H}_{2}$, thus decreasing the risk of carbon deposition as demonstrated in [41].

Nevertheless, high steam contents might lead to the reoxidation of the nickel catalyst (see Eq. (5)) resulting not only in a decrease of active sites and therefore performance losses, but also in the growth of nickel grains resulting in mechanical anode degradation. This degradation of anodic nickel is described in [42] for a direct coupling of a SOFC with a gasifier as well as theoretically in [43].

$$
\begin{gathered}
\mathrm{Ni}+\mathrm{H}_{2} \mathrm{O} \Leftrightarrow \mathrm{H}_{2}+\mathrm{NiO} \\
\Delta_{R} H_{m}{ }^{0}=+2.13 \mathrm{~kJ} / \mathrm{mol}
\end{gathered}
$$

Furthermore, a hot/dry gas cleaning is suggested as the most promising for the coupling of SOFCs with gasifiers.

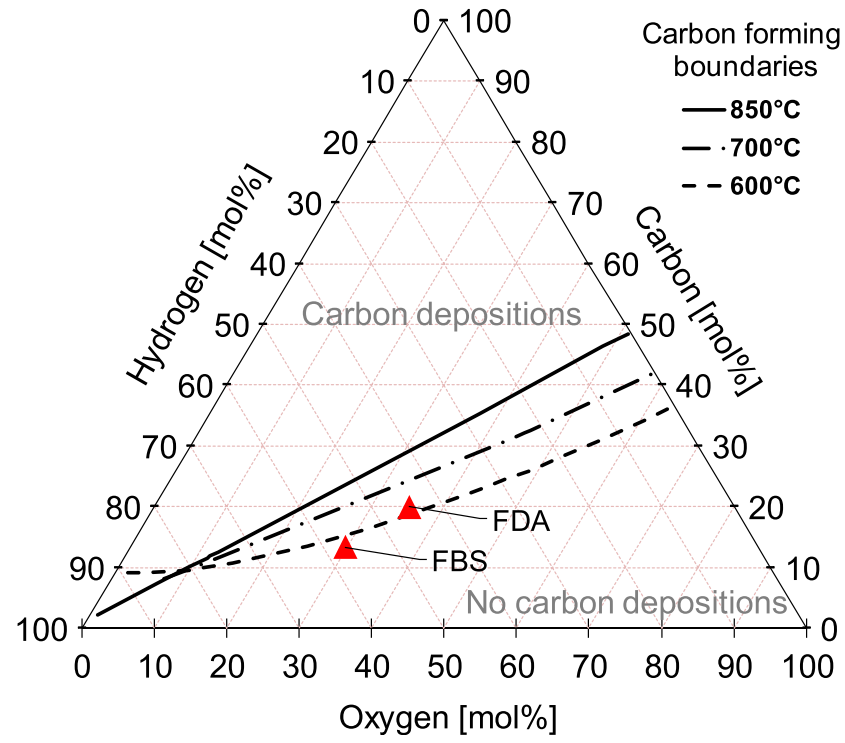

Fig. $2 \mathrm{C}-\mathrm{H}-\mathrm{O}$ ternary diagram showing carbon forming boundaries at thermodynamic equilibrium based on Gibbs energy minimization method 
With this cleaning option, all contaminants beside tars could be removed, including dust and sulfur compounds [3]. Hot/ dry gas cleaning improves the system efficiency avoiding steam condensation as assessed for the FDA case in an $\mathrm{Ni} /$ YSZ ASC SOFC in [33]. Besides, literature suggests that cell degradation can be avoided with the expected tar concentrations for cells with $\mathrm{Ni} / \mathrm{GDC}$ anode [4].

Summing up, hot/dry gas cleaned FBS gasifier product gases seem to be the most promising biomass gasification fuels for SOFCs. However, the gas compositions used for experimental investigations in this work are defined to ensure validity of the results for both gasifier configurations (FBS and FDA).

\subsubsection{Operating temperature}

As stated in [3, 33], the highest electric efficiency of a gasifier-SOFC system can be reached with hot/dry gas cleaning. To ensure a high deposition rate of contaminants like sulfur or chlorine compounds in adsorption cleaners, gas temperatures have to stay below ca. $600{ }^{\circ} \mathrm{C}$ [29]. As a result, SOFC operating temperatures as low as possible would be beneficial for the system efficiency as less heat has to be used for re-heating the cleaned product gas for SOFC operation. However, the ion conductivity of an electrolyte material decreases with increasing temperature. Due to the thicker electrolyte layer, ESCs require higher operating temperatures than ASCs to keep ohmic resistances low. As an Ni/ GDC ESC was used for the experiments, an operating temperature of $850{ }^{\circ} \mathrm{C}$ was chosen to ensure low ohmic resistances. Moreover, higher operating temperatures decrease the risk of carbon depositions as presented in [40] as well as catalyst poisoning shown in [44] for sulfur compounds.

\subsection{Scope of work}

This work aims to quantify the influence of main gas components from biomass gasification $\left(\mathrm{H}_{2}, \mathrm{CO}, \mathrm{CH}_{4}, \mathrm{CO}_{2}, \mathrm{H}_{2} \mathrm{O}\right.$, $\mathrm{N}_{2}$ ) on the performance of an Ni/GDC ESC with industrialrelevant size. Results are then used to define gas composition parameters beneficial to enhance cell performance and efficiency for this promising cell configuration for available biomass gasifier configurations. Moreover, the possible risk of degradation caused by fuel electrode re-oxidation in a steamrich atmosphere, which is a major concern in literature, is evaluated via a $500 \mathrm{~h}$ stability experiment. The risk of degradation by carbon depositions is neglected in this case due to the high steam to carbon ratio when a steam-rich gas composition is used. The obtained results will help bringing SOFCs as power generators in biomass-based combined-heat-power systems one step closer to commercialization.

\section{Experimental}

\subsection{Assembly and start up procedure}

An industrial-size $\left(10 \times 10 \mathrm{~cm}^{2}\right)$ ESC SOFC with $80 \mathrm{~cm}^{2}$ active surface was used for the experimental investigations. The cell consisted of a $40 \mu \mathrm{m} \mathrm{Ni} / \mathrm{GDC}$ anode, a $45 \mu \mathrm{m}$ lanthanum strontium manganite (LSM) cathode and a $165 \mu \mathrm{m}$ scandia stabilized zirconia (SSZ) electrolyte. A detailed description of the cell structure and materials can be found in [45] as well as in [46]. The cell was placed in an alumina housing developed in-house with nickel and platinum meshes used for the electrical contacting of anode and cathode, respectively. Further information of the alumina cell holder design can be found elsewhere [32]. The alumina cell housing enables EIS measurements with minimal cross influences from the periphery to ensure an accurate representation of electrochemical cell characteristics. Gas tightness between the anode and cathode side was ensured by using G018-394 glass powder from SCHOTT AG as sealing compound at the outer edges of the cell. The cell holder was placed in the furnace of a test rig shown in Fig. 3. A gas conditioning system was used to apply dry or humidified gas mixtures containing $\mathrm{N}_{2}, \mathrm{H}_{2}, \mathrm{H}_{2} \mathrm{O}, \mathrm{CO}, \mathrm{CO}_{2}$, and $\mathrm{CH}_{4}$ to the cell. Gas cylinders were supplied by AirLiquide AG. Humidification of the anodic gas flow was realized with a bubbler system.

The oven temperature was increased with a gradient of max. $1 \mathrm{~K} / \mathrm{min}$ to the melting temperature of the glass sealing at $900{ }^{\circ} \mathrm{C}$. After $90 \mathrm{~min}$, the glass was expected to be fully melted and the oven temperature was decreased to the final temperature of $850{ }^{\circ} \mathrm{C}$ with $0.5 \mathrm{~K} / \mathrm{min}$ to ensure complete recrystallization of the glass sealing. The reduction of anodic $\mathrm{NiO}$ to $\mathrm{Ni}$ and therefore activation of the cell was conducted by applying $1 \mathrm{slpm} \mathrm{N}_{2}$ with an $\mathrm{H}_{2}$ content increasing from 5 vol $\%$ to 45 vol $\%$ within $16 \mathrm{~h}$. Finally, the cell was loaded with $100 \mathrm{~mA} / \mathrm{cm}^{2}$ for $24 \mathrm{~h}$ and stable operation verified prior to starting the measurements.

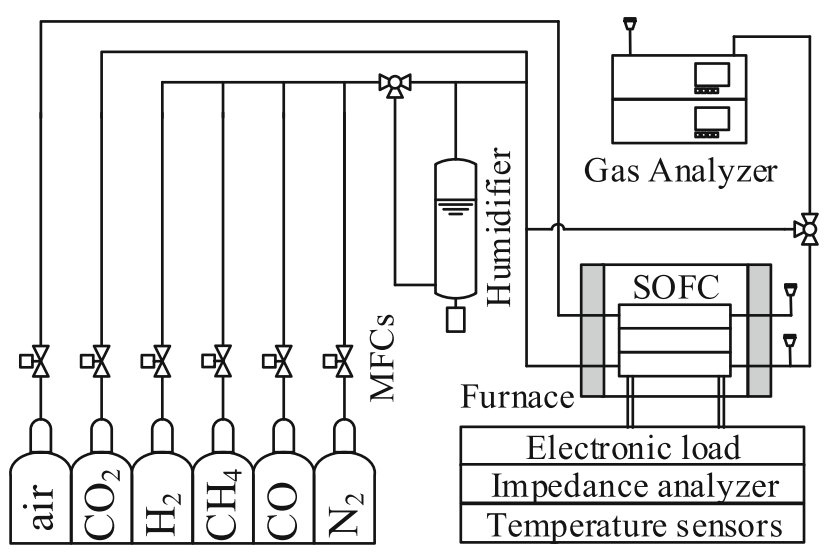

Fig. 3 Test rig scheme based on [25] 


\subsection{Measuring setup}

Current-voltage characterization as well as EIS measurements were conducted using a Bio-Logic SAS SP-150 analyzer. A Bio-Logic SAS VMP3B-80A/3 V booster was used to perform experiments up to $80 \mathrm{~A}$ electrical load. The maximum load was restricted by a minimum cell voltage of $0.7 \mathrm{~V}$. At higher loads and therefore voltages below $0.7 \mathrm{~V}$, nickel reoxidation is thermodynamically possible due to a sufficient high oxygen partial pressure at the anode, as described in $[47,48]$. The load was applied at a rate of $5 \mathrm{mV} / \mathrm{s}$ to avoid significant temperature changes in the cell holder according to [49].

Galvanostatic EIS measurements were conducted in a frequency range from $100 \mathrm{mHz}$ to $10 \mathrm{kHz}$ with 20 frequencies per decade at open circuit voltage (OCV) and under load. A sinusoidal current signal was superimposed on the DC current with an amplitude increased with increasing DC, considering a voltage response amplitude not exceeding $10 \mathrm{mV}$, as recommended in $[14,50]$. Four voltage measurements per frequency were conducted and averaged to decrease the risk of measurement errors.

Temperatures on the anode side were recorded by type $\mathrm{N}$ thermocouples in the center and the border area of the flow field at 3 points along the flow direction within the alumina housing, as schematically shown in [51]. Hence, measured values do not represent punctual but area-averaged temperatures.

Moreover, a continuous off-gas and temporary feed-gas analysis was conducted using an ABB Advanced Optima 2000 gas analyzer with an Uras 14 and Caldos 17 module. To investigate microstructural phenomena, post-mortem analyses were performed with a Zeiss Ultra 55 equipped with a field emission scanning electron microscope (SEM) and an energy-dispersive $\mathrm{X}$-ray spectroscope (EDX).

\subsection{Parameter study}

To investigate the influence of main gas components relevant for biomass gasification product gases on the cell performance, the $\mathrm{N}_{2}$ content of a gas mixture containing $50 \mathrm{vol} \%$ $\mathrm{H}_{2}$ in $\mathrm{N}_{2}$ was substituted by $\mathrm{H}_{2} \mathrm{O}, \mathrm{CO}, \mathrm{CH}_{4}$ and $\mathrm{CO}_{2}$ compounds at $850{ }^{\circ} \mathrm{C}$ regulated oven temperature and $2 \mathrm{slpm}$ anodic and cathodic gas flow rates. Table 2 gives an overview of (i) the gas mixtures applied for the cell characterization, (ii) the LHVs of the mixtures as well as (iii) the fuel utilization $\left(U_{\mathrm{f}}\right)$ at $300 \mathrm{~mA} / \mathrm{cm}^{2}$ electric load for 2 slpm fuel flow rate. Mixture ID3 was used as reference gas mixture when adding carbonaceous species $\mathrm{CO}, \mathrm{CH}_{4}$, and $\mathrm{CO}_{2}$. The background for defining this mixture as reference will be argued in subsequent sections. Studies on dry $\mathrm{H}_{2} / \mathrm{N}_{2}$ mixtures are neglected in this paper due to minor relevance for biomass gasifiers. Moreover, it is generally known that an increase of the nitrogen compound leads to a performance decrease due to (i) a lower partial pressure of the fuel gases and therefore a lower chemical potential (dilution effect) and (ii) higher diffusion losses of the reactive species to the active centers (concentration polarization) as presented in $[22,28]$.

After starting up an operating point and before each measurement, a stable cell condition considering OCV, temperature distribution within the ceramic cell holder as well as outlet gas composition was waited for. Depending on the gas composition, this stabilization period could last up to $1 \mathrm{~h}$. For each operating point, a detailed electrochemical analysis was conducted by means of currentvoltage curves as well as EIS analyses at OCV and several load levels. Cell characteristics were compared at $300 \mathrm{~mA} / \mathrm{cm}^{2}$ electric load. Temperatures on the anode side within the ceramic cell holder were measured at OCV, full-load and intermediate load after a stabilization period. Equilibrium calculations for each operating point were conducted using the Gibbs energy minimization method, thus helping to interpret changes in cell characteristics. Changes in the cell performance were analyzed by comparing following parameters with each other:

1. The LHV representing the energy content of the fuel gas.

2. The OCV as electric potential difference between anode and cathode at zero load for a defined gas mixture. Especially for wet gas mixtures resulting in low activation polarization and a linear current-voltage correlation in the low load range, the OCV represents the performance potential of the cell for a specific fuel gas mixture [21]. Considering a simultaneous electrochemical oxidation of $\mathrm{H}_{2}$ and $\mathrm{CO}$ according to Eq. (6), the OCV can be described by the Nernst equation (see Eq. (7)) using following parameters: $F$ as the Faraday Constant; $R_{\mathrm{m}}$ as molar gas constant; $n_{\mathrm{el}}$ as the number of electrons used for the $\mathrm{H}_{2}$ and $\mathrm{CO}$ oxidation reaction $\left(n_{\mathrm{el}}=4\right) ; \Delta_{\mathrm{R}} \mathrm{G}_{\mathrm{m}}{ }^{0}$ as the molar standard Gibbs enthalpy of reaction as well as $\gamma^{\text {st }}{ }_{i}$ as the stoichiometric coefficients of the reactants and products of Eq. (6); $p_{\mathrm{i}}$ as the partial pressure of $\mathrm{H}_{2}, \mathrm{CO}$, $\mathrm{H}_{2} \mathrm{O}$ and $\mathrm{CO}_{2}$ on the anode side and $\mathrm{O}_{2}$ on the cathode side as well as $p_{0}$ as the standard pressure. The direct electrochemical oxidation of $\mathrm{CH}_{4}$ plays a minor role compared with the $\mathrm{CO}$ and $\mathrm{H}_{2}$ oxidation according to [10]. Therefore, it is neglected in the Nernst equation (see Eq. (7)).

$$
\begin{aligned}
& \mathrm{H}_{2}+\mathrm{CO}+\mathrm{O}_{2} \Rightarrow \mathrm{H}_{2} \mathrm{O}+\mathrm{CO}_{2} \\
& \Delta_{R} H_{m}{ }^{0}=-525 \mathrm{~kJ} / \mathrm{mol} \\
& \mathrm{OCV}=\frac{-\Delta_{\mathrm{R}} G_{\mathrm{m}}{ }^{0}}{F n_{\mathrm{el}}}-\frac{R_{\mathrm{m}} T}{F n_{\mathrm{el}}} \ln \prod_{\mathrm{i}}\left(\frac{p_{\mathrm{i}}}{p_{0}}\right)^{\gamma^{\mathrm{st}}{ }_{i}}
\end{aligned}
$$


Table 2 Operating points for the parameter study

\begin{tabular}{llllllllll}
\hline ID & $\begin{array}{l}850{ }^{\circ} \mathrm{C} \\
2 \mathrm{slpm}\end{array}$ & $\begin{array}{l}\mathrm{H}_{2} \\
{[\text { vol\% w.b. }}\end{array}$ & $\begin{array}{l}\mathrm{H}_{2} \mathrm{O} \\
\mathrm{C}\end{array}$ & $\mathrm{CO}$ & $\mathrm{CH}_{4}$ & $\mathrm{CO}_{2}$ & $\mathrm{~N}_{2}$ & $\begin{array}{l}\mathrm{LHV} \\
{\left[\mathrm{MJ} / \mathrm{Nm}^{3}\right]}\end{array}$ & $\begin{array}{l}U_{\mathrm{f}} \text { at } 300 \mathrm{~mA} / \mathrm{cm}^{2} \\
{[\%]}\end{array}$ \\
\hline 1 & Influence $\mathrm{H}_{2} \mathrm{O}$ & 50 & 5 & & & & 45 & 5.54 & 16.7 \\
2 & & 50 & 10 & & & & 40 & 5.54 & 16.7 \\
3 & & 50 & 25 & Reference & & 25 & 5.54 & 16.7 \\
4 & & 50 & 50 & & & & & 5.54 & 16.7 \\
5 & Influence $\mathrm{CO}$ & 50 & 25 & 5 & & & 20 & 6.17 & 15.2 \\
6 & & 50 & 25 & 10 & & & 15 & 6.79 & 13.9 \\
7 & & 50 & 25 & 25 & & & & 8.68 & 11.1 \\
8 & Influence $\mathrm{CH}_{4}$ & 50 & 25 & & 5 & & 20 & 7.33 & 11.9 \\
9 & & 50 & 25 & & 10 & & 15 & 9.12 & 9.3 \\
10 & & 50 & 25 & & 25 & & & 14.49 & 5.6 \\
11 & Influence $\mathrm{CO}_{2}$ & 50 & 25 & & & 15 & 10 & 5.54 & 16.7 \\
12 & & 50 & 25 & 5 & & 15 & 5 & 6.17 & 15.2 \\
13 & & 50 & 25 & & 5 & 15 & 5 & 7.33 & 11.9 \\
14 & & 50 & 25 & 5 & 5 & 15 & & 7.96 & 11.1 \\
\hline
\end{tabular}

3. The cell voltage response $U$ to a current density $i$ of $300 \mathrm{~mA} / \mathrm{cm}^{2}$ as an indicator for the electrical power output. It can be described according to Eq. (8) and Fig. 4a as the OCV minus the sum of voltage losses $\Delta U_{\text {loss }}$ from ohmic and polarization resistance of the cell $R_{\Omega}$ and $R_{\mathrm{Pol}}$, respectively.

$$
U=\mathrm{OCV}-\Delta U_{\mathrm{loss}}=\mathrm{OCV}-i A\left(R_{\Omega}+R_{\mathrm{Pol}}\right)
$$

Polarization losses are defined as the sum of losses related to reaction activation (activation polarization) and mass transport limitations (concentration polarization) as shown in Fig. $4 \mathrm{~b}$.

4. The area specific resistance (ASR) at a current density $i$ of $300 \mathrm{~mA} / \mathrm{cm}^{2}$ representing the sum of all losses

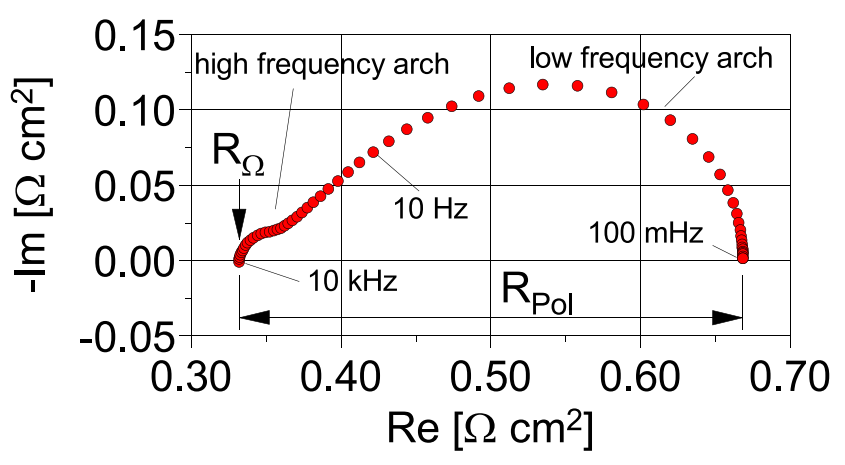

a) representative EIS spectrum within the cell according to Eq. (9), therefore representing the slope of a linear current-voltage curve.

$\mathrm{ASR}=\frac{\Delta U_{\text {loss }}}{i}\left[\Omega \mathrm{cm}^{2}\right]$

5. The fuel utilization $U_{\mathrm{f}}$ according to Eq. (10) with $\dot{n}_{\text {FuelIn }}$ as molar flow of the components $\mathrm{H}_{2}, \mathrm{CO}$, and $\mathrm{CH}_{4}$ at the SOFC inlet at an electric load $i$ of $300 \mathrm{~mA} / \mathrm{cm}^{2}$ [21].

$U_{\mathrm{f}}=\frac{i A}{F n_{\text {el }} \dot{n}_{\text {FuelIn }}}[\%]$

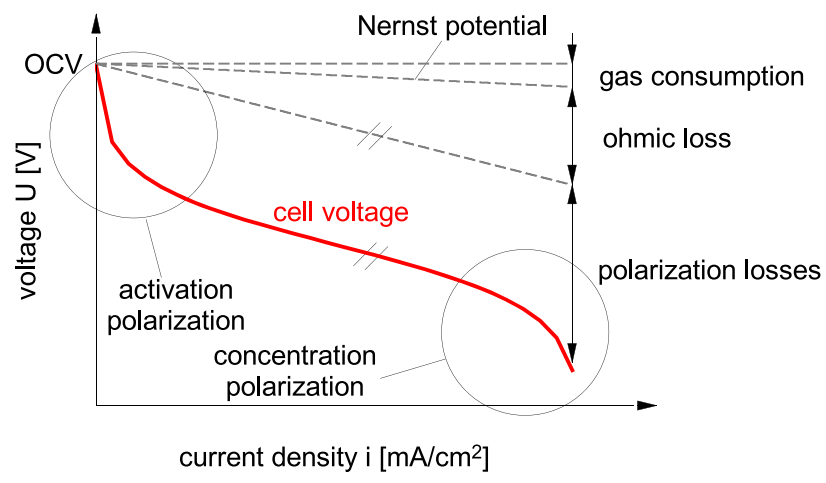

b) representative current-voltage curve

Fig. 4 EIS spectrum representing cell resistances and the impact of these resistances on a current-voltage curve [21] 
6. The electric efficiency $\eta_{\mathrm{el}}$ at an electric load $i$ of $300 \mathrm{~mA} /$ $\mathrm{cm}^{2}$. As shown in Eq. (11), it represents the efficiency of a fuel cell in converting chemical energy in electrical energy neglecting spare fuel by considering the fuel utilization $U_{\mathrm{f}}$. This approach enables to compare efficiencies of single cells fueled with gas compositions of different LHV.

$\eta_{\mathrm{el}}=\frac{U i A}{\dot{V}_{\text {Anode }} U_{\mathrm{f}} \text { LHV }_{\text {Mixture }}}[\%]$

Subsequently, a new cell was assembled and fueled with an FBS and FDA gas composition according to Table 1. Performance differences were discussed considering the key findings of the parameter study due to the importance of these gasification technologies for commercial applications. Moreover, potentials to increase the performance, especially for the FDA case, were highlighted.

\subsection{Stability test}

In addition to experiments with varying fuel gas composition for cell characterization, the cell was run on a simulated product gas representing the output of an in-house FBS wood pellet gasifier at a temperature of $800{ }^{\circ} \mathrm{C}$ for $500 \mathrm{~h}$. Results of this experiments will be used as well for comparisons with results of future experiments with (i) contaminants added to the simulated FBS gasifier product gas and (ii) real product gases from the gasifier. The gas composition used for the experiments of the FBS gasifier is shown in Table 3.

The higher $\mathrm{N}_{2}$ content in comparison to the FBS mixture presented in Table 1 results from pressurizing the fuel tank with $\mathrm{N}_{2}$ necessary for the operation of the in-house FBS gasifier. A constant load of $300 \mathrm{~mA} / \mathrm{cm}^{2}$ was applied and the current-voltage-curves as well as EIS-spectra were recorded

Table 3 Product gas composition of an in-house FBS gasifier used for the stability experiment compared to common FBS values based on [34-36] and internal data

\begin{tabular}{lll}
\hline vol\% w.b. & FBS & FBS in-house \\
\hline $\mathrm{H}_{2}$ & 24 & 22 \\
$\mathrm{H}_{2} \mathrm{O}$ & 37 & 36 \\
$\mathrm{CO}$ & 15 & 11 \\
$\mathrm{CO}_{2}$ & 13 & 11 \\
$\mathrm{CH}_{4}$ & 7 & 5 \\
$\mathrm{~N}_{2}$ & 4 & 15 \\
$\mathrm{SCR}$ & 1.68 & 2.25 \\
$\mathrm{H}_{2} / \mathrm{CO}$ & 1.6 & 2 \\
$\mathrm{H}_{2} \mathrm{O} / \mathrm{CH}$ & 5.29 & 7.2 \\
$\mathrm{LHV}\left[\mathrm{MJ} / \mathrm{Nm}_{4}{ }^{3}\right.$ w.b.] & 7.05 & 5.61 \\
\hline
\end{tabular}

every $2 \mathrm{~h}$ to track the degradation behavior as a result of possible nickel re-oxidation within the anode cermet in this steam-rich environment. Afterwards, SEM and EDX analyses were conducted to investigate changes in the anode.

\section{Results and discussion}

This section presents and discusses the results of the described parameter study and a stability experiment in order to define gas compositions and operating conditions advantageous for an efficient coupling of gasifiers with SOFCs while avoiding cell degradation.

\subsection{Parameter study}

Firstly, the results of the parameter study are presented to depict the sensitivity of cell performance when varying each main gas component relevant for product gases from biomass gasification. Therefore, the abovementioned cell parameters LHV, OCV, $U$, ASR, $U_{\mathrm{f}}$ and $\eta_{\mathrm{el}}$ are illustrated in Fig. 5 to demonstrate the main differences of cell performance for the operating conditions shown in Table 2. The oven temperature for all operating points was set to $850^{\circ} \mathrm{C}$, and the cell was fed with anodic and cathodic gas flow rates of 2 slpm.

The results of the electrochemical characterization for each gas component highlighted in Fig. 5 are presented below. At this stage, it also has to be mentioned that there is a strong influence of the fuel flow rate on the kinetic of reactions occurring in the anode, thus influencing the cell performance as stated in [24]. However, these effects are not considered in this work as a constant volume flow rate of $2 \mathrm{slpm}$ was applied.

\subsection{1 $\mathrm{H}_{2} \mathrm{O}$}

In the first place, changes of the cell characteristics were investigated when substituting the $\mathrm{N}_{2}$ content of a $50 / 50 \mathrm{vol} \%$ $\mathrm{H}_{2} / \mathrm{N}_{2}$ fuel gas mixture with $\mathrm{H}_{2} \mathrm{O}$, in order to identify a reference gas mixture for the following operating points with carbonaceous gas species $\mathrm{CO}, \mathrm{CH}_{4}$ and $\mathrm{CO}_{2}$ (ID5-ID14). The reference mixture should (i) contain $\mathrm{H}_{2} \mathrm{O}$ in the range of a typical FBS and FDA gasifier product gas according to Table 1 to enable methane steam reforming (MSR, see Eq. (12)) and water gas shift (WGS) reactions (Eq. (2)) in a comparable extent and (ii) provide enough $\mathrm{N}_{2}$ spare volume flow for the substitution with carbonaceous gas species at an unchanged total volume flow of 2 slpm.

$$
\begin{gathered}
\mathrm{CH}_{4}+\mathrm{H}_{2} \mathrm{O} \Leftrightarrow \mathrm{CO}+3 \mathrm{H}_{2} \\
\Delta_{R} H_{m}{ }^{0}=+226 \mathrm{~kJ} / \mathrm{mol}
\end{gathered}
$$

Figure 5 shows a steady decrease of the OCV and the cell voltage $U$ when increasing the $\mathrm{H}_{2} \mathrm{O}$ concentration of gas 


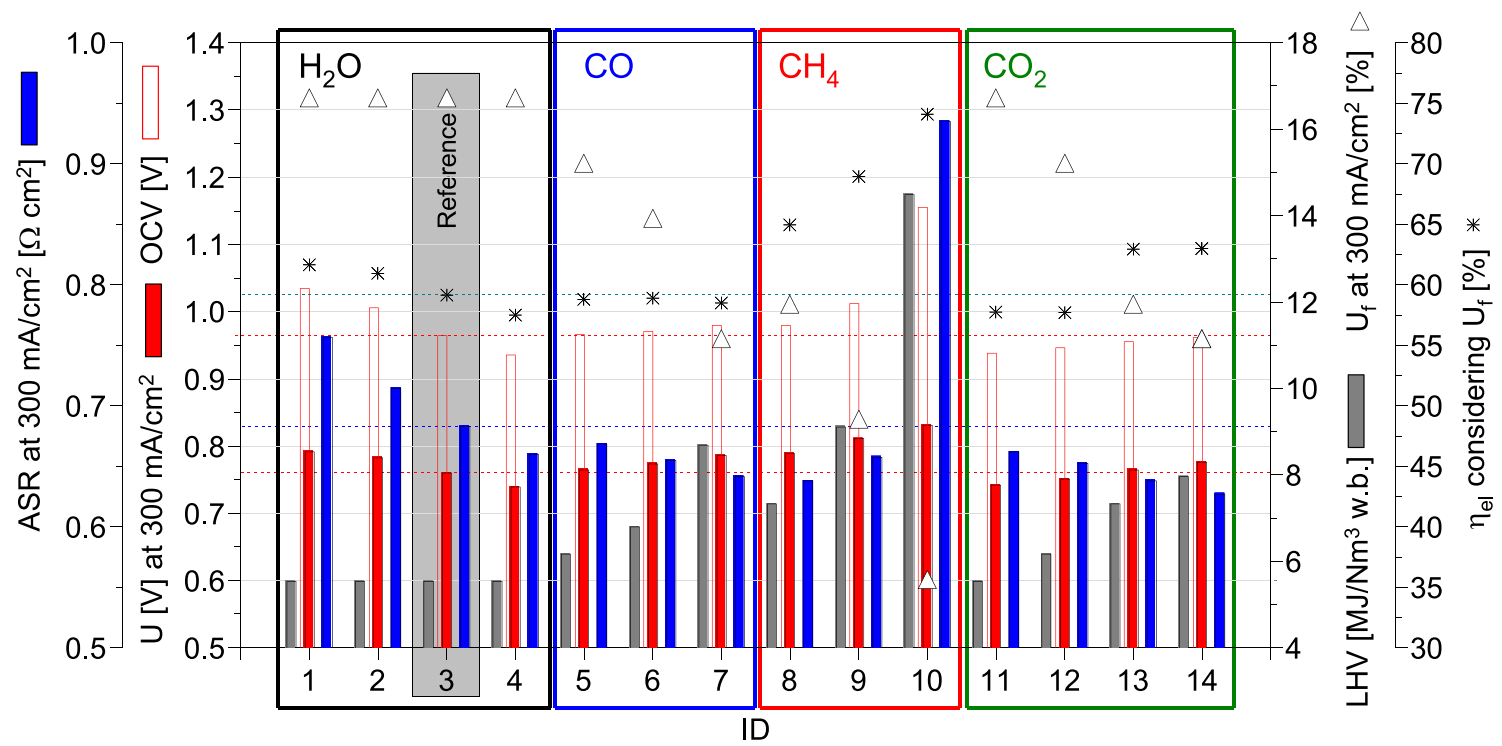

Fig. 5 Overview of cell and fuel gas parameters as well as calculated efficiencies for the investigated operating points. $U$, ASR, $U_{\mathrm{f}}$, and $\eta_{\mathrm{el}}$ are presented for an electric load of $300 \mathrm{~mA} / \mathrm{cm}^{2}$ at stable operation

composition from ID1 with 5 vol\% to ID4 with 50 vol\%, respectively. This decrease of the $\mathrm{OCV}$ when increasing the $\mathrm{H}_{2} \mathrm{O}$ concentration can be explained as follows: Higher fractions of the products of the electrochemical oxidation reaction (see Eq. (6)), $\mathrm{H}_{2} \mathrm{O}$ and $\mathrm{CO}_{2}$, decrease the second term of the Nernst equation (see Eq. (7)). This leads to a decrease of the electrochemical potential despite an unchanged LHV of the fuel gas, which is an undesired effect.

However, increasing the water content of a gas mixture containing $\mathrm{H}_{2}$ also decreases cell losses related to the activation of the electrochemical oxidation reaction (see Eq. (6)) (activation polarization) and therefore the ASR as shown in Fig. 5. This increases the linearity of the current-voltage correlation of a cell at low electric loads as described in [22] for $\mathrm{H}_{2}$ oxidation in presence of $\mathrm{H}_{2} \mathrm{O}$ and in [25] for $\mathrm{CO}$ oxidation in presence of $\mathrm{CO}_{2}$. The investigated cell showed a non-linear voltage response when fueled with gas composition ID1 ( $5 \mathrm{vol} \% \mathrm{H}_{2} \mathrm{O}$ ) in the low load range, which can be seen in Fig. 6a. For compositions ID2-ID4 (10-50 vol\% $\left.\mathrm{H}_{2} \mathrm{O}\right)$, the current-voltage curves shifted downwards in the diagram but obtained a nearly constant curve-gradient, depicting minor activation polarization. Figure $6 \mathrm{~b}$ visualizes impedance data for operating points ID1 to ID4 at a DC of $300 \mathrm{~mA} / \mathrm{cm}^{2}$ showing a steady decrease of the polarization resistance $R_{\mathrm{Pol}}$ when increasing the water content from 5 to 50 vol\%, hence reconfirming the reduction of overall losses. The slight changes of the ohmic resistances $R_{\Omega}$ can be attributed to minor changes of the cell temperature between the operating points and will be neglected due to the significant lower impact on the overall cell performance in comparison to the changes of $R_{\mathrm{Pol}}$. Moreover, the spectrum of ID1 depicts a third arch compared with the spectra of ID2-ID4. This might correlate to the non-linear part of the current-voltage curve of ID1 presented in Fig. 6a and therefore to higher activation losses as described in [22].

A decrease of voltage losses is in general desirable for an efficient operation of SOFCs. For a $\mathrm{H}_{2} \mathrm{O}$ fraction of up to $10 \mathrm{vol} \%$, the smaller voltage losses due to reduced activation polarization compensate the reduced $\mathrm{OCV}$ due to a higher $\mathrm{H}_{2} \mathrm{O}$ partial pressure according Eq. (7). This leads to a nearly constant cell voltage at $300 \mathrm{~mA} / \mathrm{cm}^{2}$ comparing ID1 with ID2 in Fig. 6a. At 25 vol\% (ID3) and 50 vol\% $\mathrm{H}_{2} \mathrm{O}$ (ID4), the OCV losses predominate leading to a decrease in cell voltage and electric efficiency.

Nevertheless, considering the before mentioned necessary comparability of the reference gas mixture to a biomass gasifier product gas, a mixture of $50 \mathrm{vol} \% \mathrm{H}_{2}$ and $25 \mathrm{vol} \% \mathrm{H}_{2} \mathrm{O}$ in $\mathrm{N}_{2}$ is employed as reference mixture for further experiments, whereas $\mathrm{N}_{2}$ will be substituted by carbonaceous species. This mixture shows best comparability to biomass gasifier product gases (see Table 1).

\subsubsection{CO}

In the next step, the $\mathrm{N}_{2}$ fraction of the previously defined reference gas mixture ID3 with $50 / 25 \mathrm{vol} \% \mathrm{H}_{2} / \mathrm{H}_{2} \mathrm{O}$ in $\mathrm{N}_{2}$ was replaced by 5,10 , and $25 \mathrm{vol} \% \mathrm{CO}$ in operating points ID5, ID6 and ID7, respectively. Substituting $\mathrm{N}_{2}$ by $\mathrm{CO}$ increases the LHV of the fuel gas as the fuel gas content of the gas mixture increases. Thus, the OCV rises with increasing $\mathrm{CO}$ content as shown in Figs. 7 and 8a.

Moreover, the equilibrium of the WGS reaction at $850{ }^{\circ} \mathrm{C}$ is strongly on the side of $\mathrm{H}_{2}$ and $\mathrm{CO}_{2}$. Table 4 shows the equilibrium compositions for gas mixtures ID5-7 at OCV in comparison to the initial input composition. 


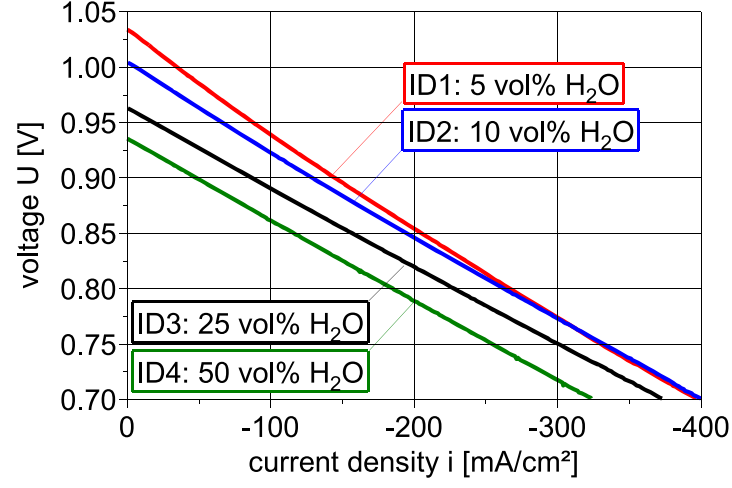

a) current voltage correlations

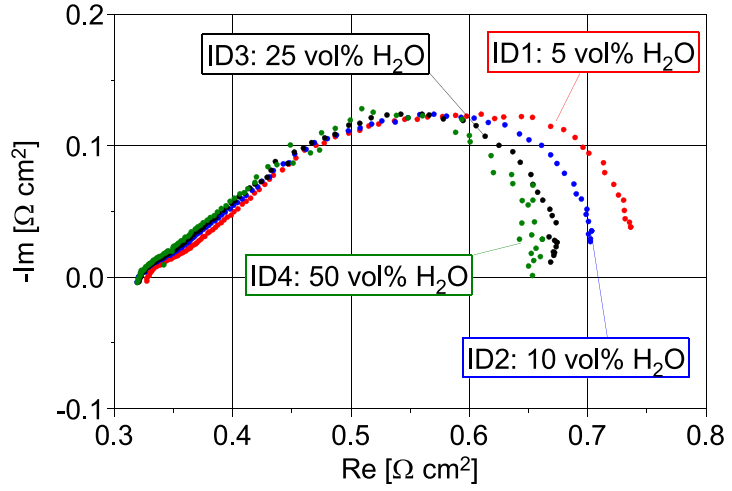

b) EIS spectra at $300 \mathrm{~mA} / \mathrm{cm}^{2}$

Fig. 6 Current-voltage correlations and EIS spectra for operating points ID1-ID4 substituting $\mathrm{N}_{2}$ with 5-50 vol\% $\mathrm{H}_{2} \mathrm{O}$. Initial composition: 50 vol\% $\mathrm{H}_{2}$ in $\mathrm{N}_{2}$

This leads to a partial conversion of $\mathrm{CO}$ with $\mathrm{H}_{2} \mathrm{O}$ to $\mathrm{H}_{2}$ and $\mathrm{CO}_{2}$ lowering the cell polarization and therefore the ASR from ID5-ID7 in comparison to the reference gas mixture ID3 due to (i) the higher reactivity of $\mathrm{H}_{2}$ in comparison to $\mathrm{CO}$ and (ii) the lower activation polarization of the $\mathrm{CO}$ oxidation reaction (see Eq. (13)) due to the presence of the reaction product $\mathrm{CO}_{2}$. In Fig. 8a, the decreasing ASR can be seen as decreasing gradient of the current-voltage curves for ID5-ID7 in comparison to ID3.

$$
\begin{gathered}
\mathrm{CO}+0.5 \mathrm{O}_{2} \Rightarrow \mathrm{CO}_{2} \\
\Delta_{R} H_{m}{ }^{0}=-282 \mathrm{~kJ} / \mathrm{mol}
\end{gathered}
$$

Comparing the current-voltage correlations of ID6 (10 vol\% CO) with ID7 (25 vol\% CO) in Fig. 8a shows no voltage difference at $300 \mathrm{~mA} / \mathrm{cm}^{2}$. However, voltages presented at $300 \mathrm{~mA} / \mathrm{cm}^{2}$ stable operation shown in Fig. 7

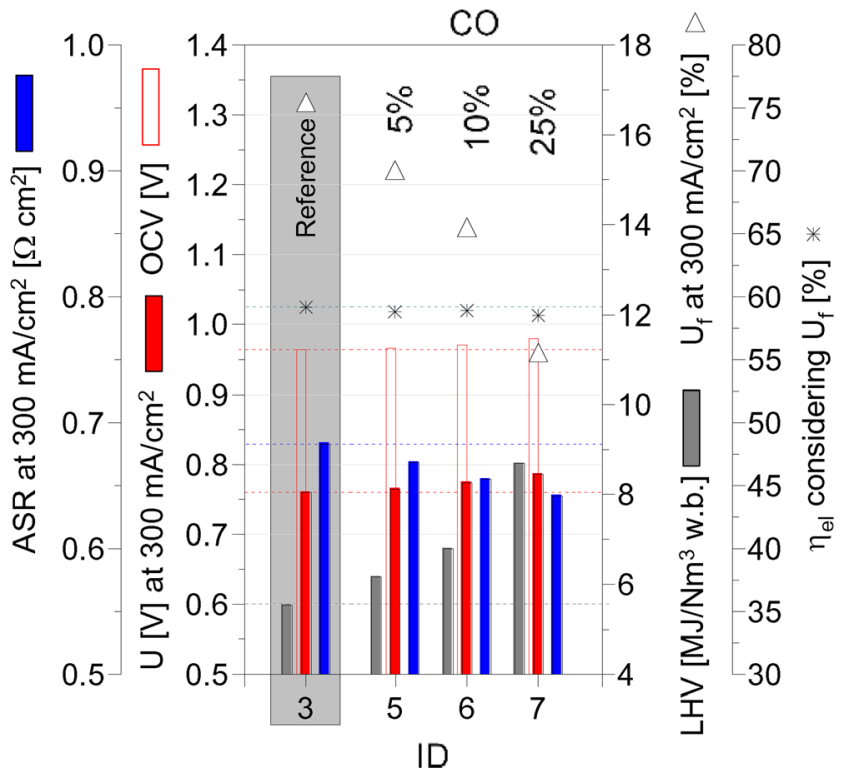

Fig. 7 Comparison of $\mathrm{CO}$ operating points with reference mixture significantly change between ID6 and ID7. It seems, that during fast load changes at $\mathrm{CO}$ concentrations higher than $10 \mathrm{vol} \%$, like for the current voltage curves in Fig. 8a recorded at $5 \mathrm{mV} / \mathrm{s}, \mathrm{CO}$ electrochemically oxidizes via reaction (13) before taking part in the comparably slow WGS reaction (see Eq. (2)). Therefore, less electrochemically more reactive $\mathrm{H}_{2}$ is formed via WGS, thus increasing cell polarization and therefore the ASR. In conclusion, a lower cell performance at fast load changes in comparison to stable operation should be taken into consideration at high $\mathrm{CO}$ concentrations in the product gas.

Summing up, a decreasing $\mathrm{H}_{2} / \mathrm{CO}$ ratio might lead to a performance reduction despite an increasing LHV of the gas mixture at fast load changes. This was explained by the major influence of the water-gas-shift reaction on the fuel utilization behavior of the cell, as $\mathrm{CO}$ preferably oxidizes before reacting with $\mathrm{H}_{2} \mathrm{O}$ to form the electrochemically better reactant $\mathrm{H}_{2}$ at fast load changes, thus lowering the power output. Nevertheless, the electric efficiency of the cell changes in a significant extent, but the fuel utilization is significantly reduced.

\subsection{3 $\mathrm{CH}_{4}$}

Third, the $\mathrm{N}_{2}$ fraction of the reference gas mixture ID3 was stepwise substituted by 5,10 and $25 \mathrm{vol} \% \mathrm{CH}_{4}$ in operating points ID8, ID9 and ID10, respectively. As $\mathrm{CH}_{4}$ has a much higher LHV than CO $(803 \mathrm{~kJ} / \mathrm{mol}$ vs. $283 \mathrm{~kJ} / \mathrm{mol})$, the LHV of mixture ID8 increases significantly in comparison to the LHV of the reference mixture ID3 and the mixture with $5 \mathrm{vol} \% \mathrm{CO}$ (ID5) as shown in Fig. 9. Gas analysis at the inlet and outlet of the cell holder at $\mathrm{OCV}$ confirmed nearly complete $\mathrm{CH}_{4}$ conversion with rates of $95 \%, 98 \%$ and $97 \%$ for operating points ID8 (5 vol\% $\left.\mathrm{CH}_{4}\right)$, ID9 (10 vol\% $\left.\mathrm{CH}_{4}\right)$ and ID10 (25 vol\% $\mathrm{CH}_{4}$ ), respectively. Table 5 also depicts a nearly full conversion of $\mathrm{CH}_{4}$ at $\mathrm{OCV}$ when comparing the initial input gas 


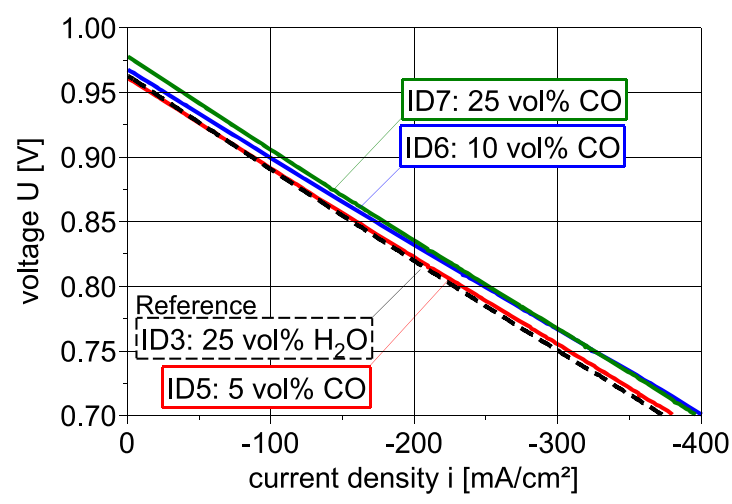

a) current voltage correlations

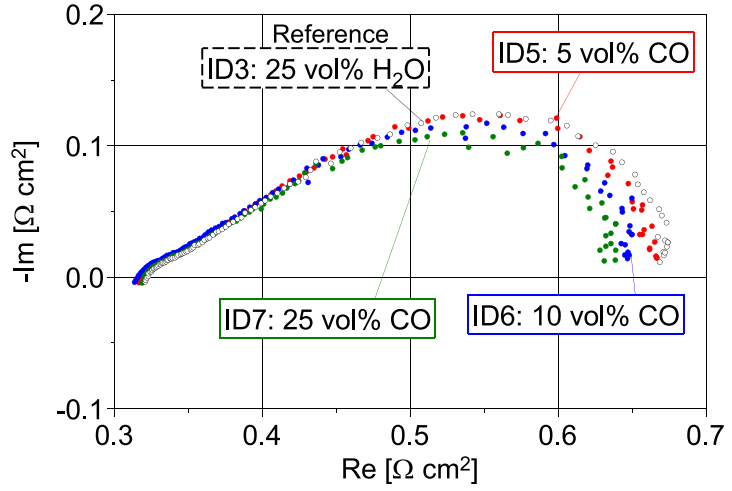

b) EIS spectra at $300 \mathrm{~mA} / \mathrm{cm}^{2}$

Fig. 8 Current-voltage correlations and EIS spectra for operating points ID5-ID7 substituting $\mathrm{N}_{2}$ with CO. Initial composition: 50/25 vol\% $\mathrm{H}_{2} / \mathrm{H}_{2} \mathrm{O}$ in $\mathrm{N}_{2}$

composition with the calculated equilibrium composition. As $1 \mathrm{~mol} \mathrm{CH}_{4}$ forms $1 \mathrm{~mol}$ of $\mathrm{CO}$ and $3 \mathrm{~mol}$ of $\mathrm{H}_{2}$ by reacting with $1 \mathrm{~mol} \mathrm{H}_{2} \mathrm{O}$ via MSR (see Eq. (12)), the volume flow within the cell increases. Table 5 shows a decreasing $\mathrm{N}_{2}$ concentration when comparing the initial input gas mixtures with the equilibrium compositions of ID8 and ID9, thus highlighting an increase of the molar flux through the cell.

The higher $\mathrm{H}_{2}$ and $\mathrm{CO}$ partial pressures in comparison to the pressures in the reference gas mixture lead to an increase of OCV and cell voltage as shown in Figs. 9 and 10a.

In contrast to the previously described substitution of $\mathrm{N}_{2}$ with $\mathrm{CO}$, the ASR strongly increases with $\mathrm{CH}_{4}$ exceeding 10 vol\% as shown in Fig. 9. This can be argued as a result of a temperature decrease at the fuel inlet due to endothermic MSR reactions (12). Analysis of the temperature distribution confirmed a decrease of the cell temperature at the fuel flow entry in comparison to the reference gas mixture ID3 of $0.5 \mathrm{~K}$ for ID8 (5 vol\% $\left.\mathrm{CH}_{4}\right), 5.5 \mathrm{~K}$ for ID9 (10 vol\% $\left.\mathrm{CH}_{4}\right)$ and $18.8 \mathrm{~K}$ for ID10 (25 vol\% $\left.\mathrm{CH}_{4}\right)$. The minor temperature decrease at 5 vol\% $\mathrm{CH}_{4}$ might be the result of heat provided for the endothermic MSR reactions by exothermic WGS reactions (see Eq. (2)), where CO produced through MSR reacts with water forming $\mathrm{H}_{2}$ and $\mathrm{CO}_{2}$, thus compensating a temperature decrease. At increasing $\mathrm{CH}_{4}$ concentrations, the MSR reactions increasingly predominate WGS reactions resulting in a temperature decrease, especially in the inlet zones of the cell [52]. A decrease in temperature therefore results in a higher ohmic resistance of the electrolyte as well as higher resistance for the activation of the electrochemical reactions also resulting in a higher cell polarization, as described in [21].
Figure 10b illustrates this increasing ohmic resistance $R_{\Omega}$ as well as polarization resistance $R_{\mathrm{Pol}}$ with increasing $\mathrm{CH}_{4}$ content. ID10 (25 vol\% $\mathrm{CH}_{4}$ ) shows a disproportionally high increase of $R_{\Omega}$ as well as $R_{\mathrm{Pol}}$. Considering the nearly full conversion of $\mathrm{CH}_{4}$ into $\mathrm{CO}$ and $\mathrm{H}_{2}$ measured with the gas analyzer and the $\mathrm{H}_{2} \mathrm{O} / \mathrm{CH}_{4}$ ratio of 1 in this gas mixture, no water will be left after MSR reactions for $\mathrm{H}_{2}$ oxidation. This leads to (i) prevented exothermic WGS reactions partially compensating the temperature decrease resulting from endothermic MSR reactions and (ii) higher activation polarization of the cell significantly increasing $R_{\mathrm{Pol}}$ as the $\mathrm{H}_{2} \mathrm{O}$ amount in a gas mixture strongly influences the kinetics of the electrochemical oxidation reactions of $\mathrm{H}_{2}$. As a result, the currentvoltage curve for ID10 (25 vol\% $\left.\mathrm{CH}_{4}\right)$ loses its linearity, especially in the low load range as shown in Fig. 10a. Moreover, the spectrum of ID10 in Fig. 10b shows three arches instead of two when comparing it to the spectra of ID3, ID8 and ID9. This correlates to the spectrum of ID1 with 5 vol\% $\mathrm{H}_{2} \mathrm{O}$ shown in Fig. 6, also depicting 3 arches. Furthermore, the polarization curves of ID1 and ID10 are non-linear in the low load range. This is described as a result of activation polarization in [22]. Therefore, this third arch can be correlated to higher activation polarization for this cell type.

Nevertheless, the electric efficiency $\eta_{\mathrm{el}}$ considering fuel utilization strongly increases with increasing $\mathrm{CH}_{4}$ concentration. This strong increase is the result of (i) a much lower fuel utilization due to the increasing volume flow resulting from the MSR reaction (12) as well as (ii) an increasing $\mathrm{H}_{2} / \mathrm{CO}$ ratio resulting from methane reforming and therefore increasing achievable performance.
Table 4 Equilibrium compositions at OCV for gas mixtures ID5-7 in comparison to the initial input compositions

\begin{tabular}{lllllll}
\hline vol\% (input | equilibrium) & $\mathrm{H}_{2}$ & $\mathrm{H}_{2} \mathrm{O}$ & $\mathrm{CO}$ & $\mathrm{CO}_{2}$ & $\mathrm{CH}_{4}$ & $\mathrm{~N}_{2}$ \\
\hline ID 5 & $50 \mid 51.4$ & $25 \mid 23.6$ & $5 \mid 3.5$ & $0 \mid 1.5$ & $0 \mid 0.0$ & $20 \mid 20.0$ \\
ID 6 & $50 \mid 52.7$ & $25 \mid 22.3$ & $10 \mid 7.3$ & $0 \mid 2.7$ & $0 \mid 0.0$ & $15 \mid 15.0$ \\
ID 7 & $50 \mid 55.8$ & $25 \mid 19.2$ & $25 \mid 19.1$ & $0 \mid 5.9$ & $0 \mid 0.0$ & $0 \mid 0.0$ \\
\hline
\end{tabular}




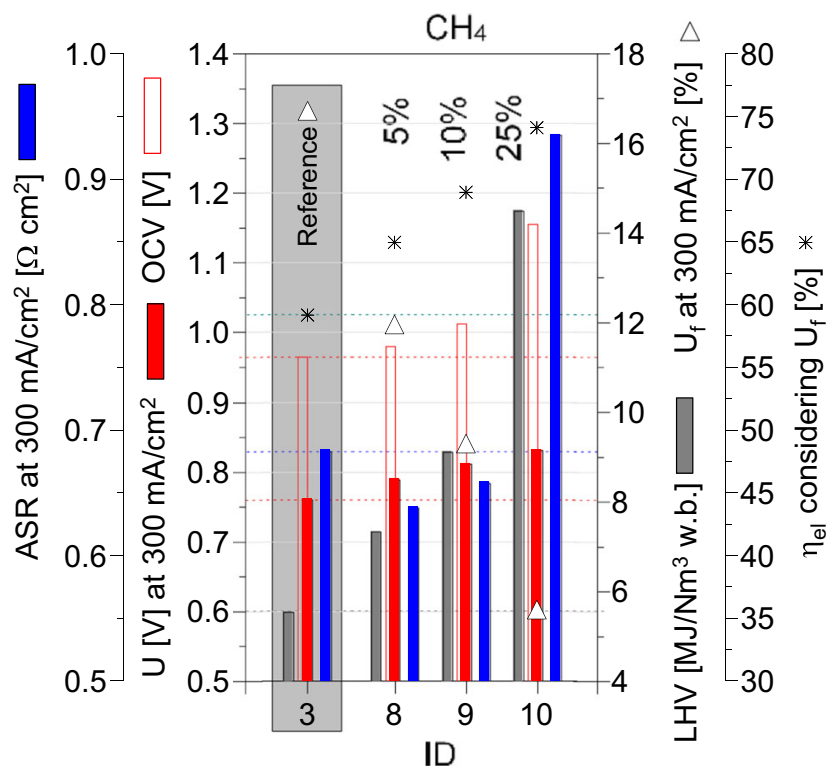

Fig. 9 Comparison of operating points with $\mathrm{CH}_{4}$ with reference mixture

Especially when comparing ID7 (25 vol\% CO) with ID8 (5 vol\% $\mathrm{CH}_{4}$ ) in Fig. 11, the small amount of $\mathrm{CH}_{4}$ significantly increases the electric efficiency of ID8 in comparison to the gas mixture ID7 with a high CO fraction of $25 \mathrm{vol} \%$. This results in a similar power output in both operating points despite a $15.6 \%$ higher LHV in ID7 compared with ID8. Therefore, even small $\mathrm{CH}_{4}$ amounts can improve the cell performance more significantly than high $\mathrm{CO}$ concentrations.

In conclusion, a $\mathrm{H}_{2} \mathrm{O} / \mathrm{CH}_{4}$ ratio higher than 1 is strongly recommended to avoid high polarization losses and ensure linearity of the current-voltage correlation especially in the low load range enabling a more stable cell operation behavior due to better controllability of the cell. Moreover, even small $\mathrm{CH}_{4}$ amounts can improve the cell performance more significantly than high $\mathrm{CO}$ concentrations and should therefore be favored.

\subsection{4 $\mathrm{CO}_{2}$}

In the last step, the $\mathrm{N}_{2}$ compound of the reference gas mixture ID3 was replaced by mixtures of carbonaceous species $\mathrm{CO}_{2}$, $\mathrm{CO}$ and $\mathrm{CH}_{4}$ in operating points ID11 to ID14. When adding $15 \mathrm{vol} \% \mathrm{CO}_{2}$ (ID11) to the reference gas mixture (ID3), the OCV strongly decreases leading to a lower cell power output despite an unchanged LHV of the fuel gas as shown in Fig. 12. This might be explained as follows: Fractions of the added $\mathrm{CO}_{2}$ will immediately react with $\mathrm{H}_{2}$ on the catalyst to form $\mathrm{CO}$ and $\mathrm{H}_{2} \mathrm{O}$ via endothermic WGS reactions (see Eq. (2)).
Table 6 shows the equilibrium compositions for gas mixtures ID11, ID5, ID12, ID8 and ID13 in comparison to the initial input compositions clearly indicating the formation of $\mathrm{CO}$ and $\mathrm{H}_{2} \mathrm{O}$ from $\mathrm{H}_{2}$ and $\mathrm{CO}_{2}$ via WGS reactions.

As described in the introduction chapter, $\mathrm{CO}$ has a lower electrochemical activity as well as electrochemical potential according the Nernst equation (see Eq. (7)) than $\mathrm{H}_{2}$ resulting in a lower $\mathrm{OCV}$. Moreover, $\mathrm{CO}_{2}$ has a higher diffusion resistance than $\mathrm{N}_{2}$ increasing diffusion losses and the concentration polarization of the cell [53]. However, an increasing $\mathrm{CO}_{2}$ concentration significantly lowers the activation polarization of the $\mathrm{CO}$ oxidation reaction (see Eq. (13)), thus lowering the ASR. But the lower cell resistances do not compensate the decreased electrochemical potential. Therefore, increasing $\mathrm{CO}_{2}$ fractions decrease the cell performance and consequently the electrical efficiency of the SOFC.

However, $\mathrm{CO}_{2}$ is a common component in biomass gasification product gases and cannot be completely avoided. For this reason, the influence of adding $15 \mathrm{vol} \% \mathrm{CO}_{2}$ to mixtures without $\mathrm{CO}_{2}$ but small amounts of $\mathrm{CO}$ and $\mathrm{CH}_{4}$ such as ID5 (5 vol\% CO) and ID8 (5 vol\% $\left.\mathrm{CH}_{4}\right)$ on the cell performance was investigated. Figure 12 depicts that adding $15 \mathrm{vol} \% \mathrm{CO}_{2}$ to a mixture with $\mathrm{CO}$ (ID5) has a lower impact on the cell efficiency than adding it to a mixture with $\mathrm{CH}_{4}$ (ID8).

This might be explained by considering the methane dry reforming reaction (Eq. (14)). The $\mathrm{H}_{2} / \mathrm{CO}$ ratio of the reaction products is smaller for methane dry reforming than for methane steam reforming ( 1 vs. 3 ). Due to the better electrochemical activity of $\mathrm{H}_{2}$ in comparison to $\mathrm{CO}$, a lower $\mathrm{H}_{2} / \mathrm{CO}$ ratio results in an increase of polarization losses, thus decreasing the cell efficiency.

$$
\begin{gathered}
\mathrm{CH}_{4}+\mathrm{CO}_{2} \Leftrightarrow 2 \mathrm{CO}+2 \mathrm{H}_{2} \\
\Delta_{R} \mathrm{H}_{m}{ }^{0}=+259 \mathrm{~kJ} / \mathrm{mol}
\end{gathered}
$$

Summing up, it can be concluded that the amount of $\mathrm{CO}_{2}$ in the gas mixture should always be kept as low as possible, especially to avoid conversion of electrochemically high-reactive $\mathrm{H}_{2}$ with $\mathrm{CO}_{2}$ to $\mathrm{CO}$ and $\mathrm{H}_{2} \mathrm{O}$ via WGS and to keep diffusion resistances for electrochemically active species low.

\subsubsection{Key findings and discussion of results}

In the first step, a reference gas mixture of 50/25 vol $\% \mathrm{H}_{2} /$ $\mathrm{H}_{2} \mathrm{O}$ in $\mathrm{N}_{2}$ was defined ensuring comparability to biomass
Table 5 Equilibrium compositions at $\mathrm{OCV}$ for gas mixtures ID8-10 in comparison to the initial input compositions

\begin{tabular}{lllllll}
\hline vol\% (input | equilibrium) & $\mathrm{H}_{2}$ & $\mathrm{H}_{2} \mathrm{O}$ & $\mathrm{CO}$ & $\mathrm{CO}_{2}$ & $\mathrm{CH}_{4}$ & $\mathrm{~N}_{2}$ \\
\hline ID8 & $50 \mid 60.0$ & $25 \mid 17.3$ & $0 \mid 3.6$ & $0 \mid 0.9$ & $5 \mid 0.0$ & $20 \mid 18.2$ \\
ID9 & $50 \mid 67.7$ & $25 \mid 11.5$ & $0 \mid 7.2$ & $0 \mid 1.1$ & $10 \mid 0.0$ & $15 \mid 12.5$ \\
ID10 & $50 \mid 81.6$ & $25 \mid 1.2$ & $0 \mid 15.5$ & $0 \mid 0.2$ & $25 \mid 1.4$ & $0 \mid 0.0$
\end{tabular}




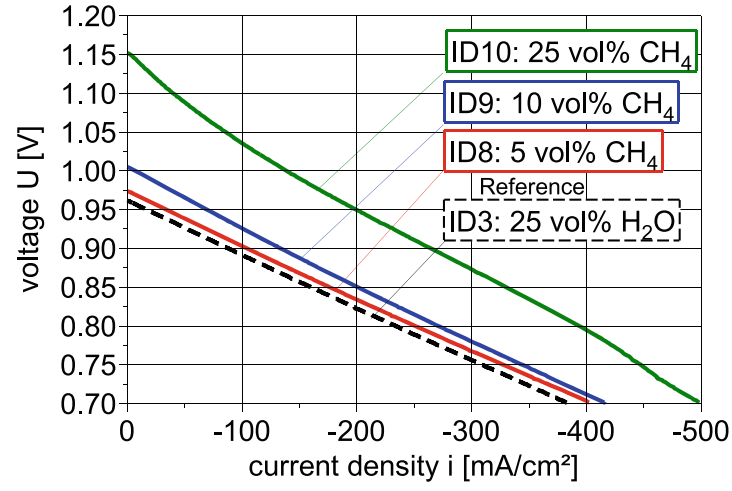

a) current voltage correlations

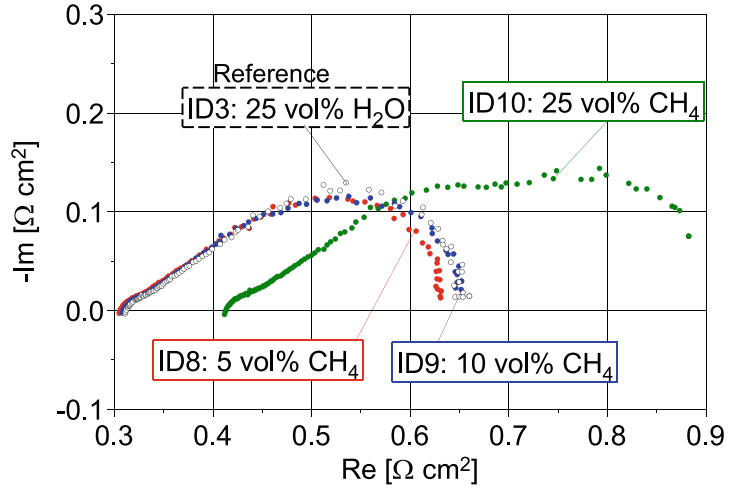

b) EIS spectra at $300 \mathrm{~mA} / \mathrm{cm}^{2}$

Fig. 10 Current-voltage correlations and EIS spectra for operating points ID8-ID10 substituting $\mathrm{N}_{2}$ with $\mathrm{CH}_{4}$. Initial composition: $50 / 25$ vol\% $\mathrm{H}_{2} / \mathrm{H}_{2} \mathrm{O}$ in $\mathrm{N}_{2}$

gasifier product gases. Substituting the $\mathrm{N}_{2}$ content with varying fractions of $\mathrm{CO}, \mathrm{CH}_{4}$ and $\mathrm{CO}_{2}$ led to following key findings:

- CO: At fast load changes, $\mathrm{CO}$ predominantly oxidizes in an electrochemical reaction before leading to the formation of $\mathrm{H}_{2}$ via WGS reactions. This results in a stagnating power output despite an increasing LHV of the fuel gas, especially at low $\mathrm{H}_{2} / \mathrm{CO}$ ratios. Therefore, the $\mathrm{H}_{2} / \mathrm{CO}$ ratio should be aimed as high as possible.

- $\mathrm{CH}_{4}: \mathrm{A} \mathrm{H}_{2} \mathrm{O} / \mathrm{CH}_{4}$ ratio below 1 results in high polarization losses and moreover in a non-linear current-voltage correlation of the cell, especially in the low load range. Therefore, a ratio higher than 1 is recommended. Moreover, even small $\mathrm{CH}_{4}$ concentrations in the fuel gas

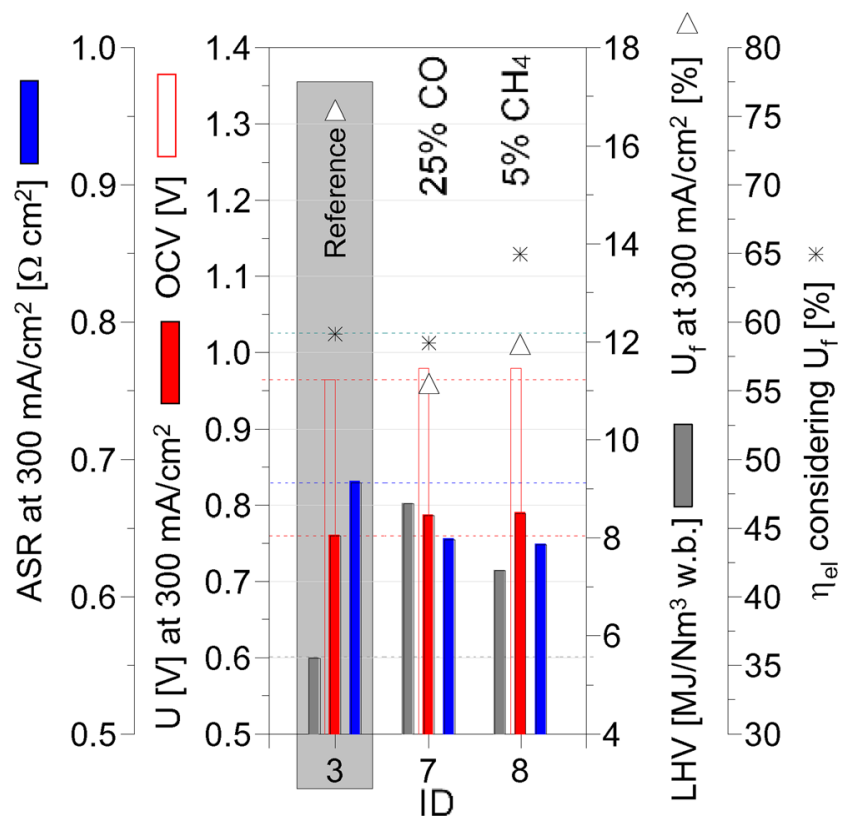

Fig. 11 Comparison of composition containing 25 vol\% $\mathrm{CO}$ to composition with $5 \mathrm{vol} \% \mathrm{CH}_{4}$ can increase the SOFC performance more significantly than high $\mathrm{CO}$ concentrations and should therefore be favored. In general, the addition of hydrocarbons with high $\mathrm{H} / \mathrm{C}$ ratio like $\mathrm{CH}_{4}$ directly steam reformed in a SOFC strongly increases the electric efficiency of a cell as long as the SCR ratio stays larger than one. Otherwise, the risk of carbon depositions [32] as well as high voltage losses due to activation polarization [22] strongly increases.

- $\mathrm{CO}_{2}: \mathrm{CO}_{2}$ in the fuel gas reacts with electrochemically high-reactive $\mathrm{H}_{2}$ to form $\mathrm{CO}$ and $\mathrm{H}_{2} \mathrm{O}$ via water gas shift reaction. Moreover, $\mathrm{CO}_{2}$ in the gas mixture increases the diffusion resistance for electrochemically active species to the heterogeneous reaction sites. Thus, the $\mathrm{CO}_{2}$ concentration should be aimed as low as possible.

As stated in the introduction, according to literature, FBS gasifier product gas is most promising for power generation in SOFCs. The key findings from the parameter study

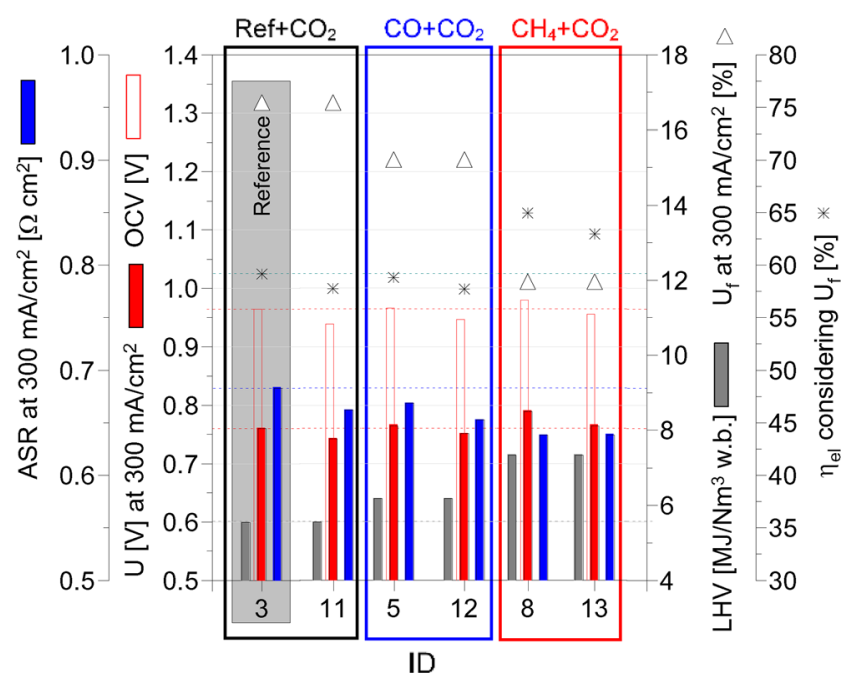

Fig. 12 Analysis of the influence of adding $15 \mathrm{vol} \% \mathrm{CO}_{2}$ to the reference mixture ID3 and mixtures ID5 (5 vol\% CO) and ID8 (5 vol\% $\left.\mathrm{CH}_{4}\right)$ 
Table 6 Equilibrium compositions at OCV for gas mixtures ID11, ID5, ID12, ID8 and ID13 in comparison to the initial input compositions

\begin{tabular}{llllrlr}
\hline vol\% (input | equilibrium) & $\mathrm{H}_{2}$ & $\mathrm{H}_{2} \mathrm{O}$ & $\mathrm{CO}$ & $\mathrm{CO}_{2}$ & $\mathrm{CH}_{4}$ & $\mathrm{~N}_{2}$ \\
\hline ID11 & $50 \mid 41.3$ & $25 \mid 33.7$ & $0 \mid 8.7$ & $15 \mid 6.3$ & $0 \mid 0.0$ & $10 \mid 10.0$ \\
ID5 & $50 \mid 51.4$ & $25 \mid 23.6$ & $5 \mid 3.5$ & $0 \mid 1.4$ & $0 \mid 0.0$ & $20 \mid 20.0$ \\
ID12 & $50 \mid 43.0$ & $25 \mid 32.0$ & $5 \mid 12.0$ & $15 \mid 8.0$ & $0 \mid 0.0$ & $5 \mid 5.0$ \\
ID8 & $50 \mid 60.0$ & $25 \mid 17.3$ & $0 \mid 3.6$ & $0 \mid 0.9$ & $5 \mid 0.0$ & $20 \mid 18.2$ \\
ID13 & $50 \mid 51.1$ & $25 \mid 26.1$ & $0 \mid 12.5$ & $15 \mid 5.7$ & $5 \mid 0.0$ & $5 \mid 4.6$ \\
\hline
\end{tabular}

contributed to this assumption as especially the advantages of a higher $\mathrm{H}_{2} / \mathrm{CO}$ ratio and $\mathrm{CH}_{4}$ content could be highlighted.

To quantify the performance increase, a new single cell was tested with the synthetic FDA and FBS gasifier product gases from Table 1, and current-voltage correlations were recorded as shown in Fig. 13. The $70 \%$ higher $\mathrm{H}_{2} /$ $\mathrm{CO}$ ratio and the $133 \%$ higher $\mathrm{CH}_{4}$ content of the FBS gasifier product gas in comparison to the FDA product gas led to efficiencies at an electric load of $200 \mathrm{~mA} / \mathrm{cm}^{2}$ of $57.6 \%$ to $61.9 \%$ for the FDA and FBS case, respectively. This increase resulted out of a significantly lower ASR and therefore flatter slope of the FBS current-voltage curve in comparison to the FDA curve. Due to the promising performance of the cell fueled with a FBS product gas, a $500 \mathrm{~h}$ stability experiment was conducted. However, higher efficiencies for proposed gas mixtures will be achieved in commercial stack applications due to a better electrical contacting of the cells and optimized flow control.

The usage of FDA product gases in a SOFC results in slightly smaller electric efficiencies and a higher risk for carbon depositions in comparison to using FBS product gases [33]. However, FDA gasifiers in combination with gas engines are an established configuration for converting solid biomass into power, especially for small power ranges [54]. Therefore, they should not be neglected as suitable systems for the coupling with SOFCs. Besides, possible strategies that could be considered for increasing the suitability of FDA product gas for SOFC applications are as follows:

- The usage of oxygen enriched air together with steam as gasification agent would significantly increase the LHV, $\mathrm{H}_{2} / \mathrm{CO}$ ratio, $\mathrm{CH}_{4} / \mathrm{CO}$ ratio and $\mathrm{SCR}$ while lowering the $\mathrm{CO}_{2}$ content. Based on the presented key findings as well as results from the literature review, this would result in an increasing electric efficiency of an SOFC as well as a decreasing risk for carbon depositions according to [32].

- The injection of steam in the product gas would be a strategy easier to conduct resulting in a higher SCR at lower LHV of the product gas, thus decreasing the risk of carbon depositions in the anode. However, the addition of steam would shift the current-voltage curve for the FDA mixture shown in Fig. 13 downwards, thus increasing the performance gap to the FBS mixture.

Not only for FDA, but also for FBS gasifiers there is a potential for improving the product gas composition for the use with SOFCs. By increasing the gasifier reactor temperature, the $\mathrm{H}_{2} / \mathrm{CO}$ ratio could be increased, however at increasing $\mathrm{CO}_{2}$ and decreasing $\mathrm{CH}_{4}$ content thus possibly decreasing the electric efficiency of the cell [55]. As proposed in [36], dual fluidized bed (DFB) gasifiers with absorption enhanced reforming (AER) are able to significantly increase the $\mathrm{H}_{2} / \mathrm{CO}$

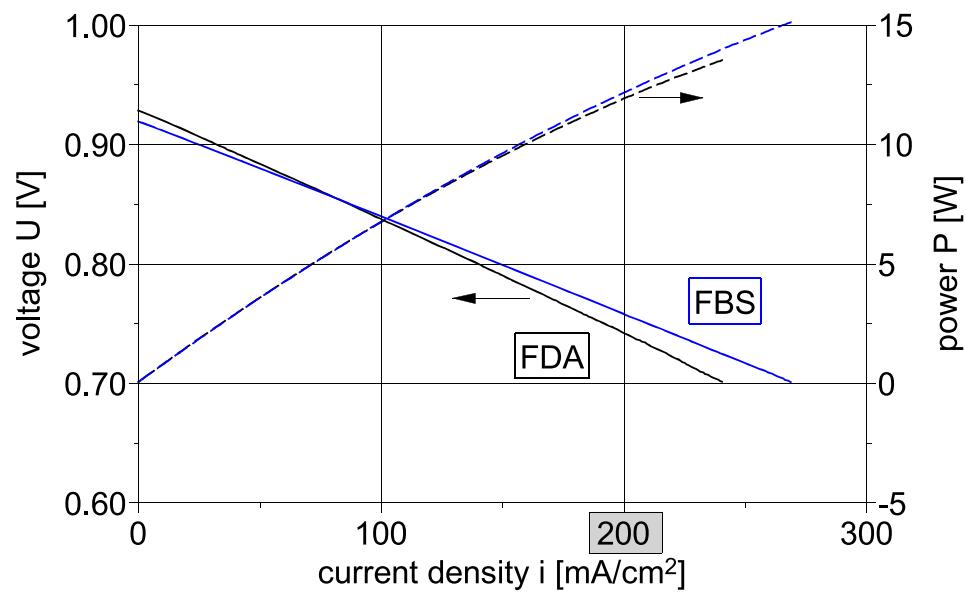

$200 \mathrm{~mA} / \mathrm{cm}^{2}$ FDA FBS $\Delta$

LHV $\left[\mathrm{MJ} / \mathrm{Nm}^{3}\right] \quad 4.99 \quad 7.05+41 \%$

$\begin{array}{llll}\text { OCV [V] } & 0.93 & 0.92 & -1 \%\end{array}$

$\begin{array}{llll}\text { U [V] } & 0.76 & 0.81 & +7 \%\end{array}$

ASR $\left[\Omega \mathrm{cm}^{2}\right] \quad 0.95 \quad 0.82-14 \%$

Uf [\%]

$\eta_{\mathrm{el}}[\%]$

$24.8 \quad 16.6-33 \%$

$57.6 \quad 61.9+7 \%$

Fig. 13 Comparison of current-voltage correlations for a single cell fueled with FDA and FBS gasifier product gas 
ratio while reducing the $\mathrm{CO}_{2}$ content to a large extent. Both potentials have to be investigated more closely in future works.

\subsection{Stability test with typical FBS composition}

Considering the key findings of the parameter study, a FBS gasifier product gas was defined as most promising for power generation in SOFCs. For this reason, the gas composition of an in-house FBS gasifier fueled with wood pellets presented in Table 3 was selected for the use as fuel gas for a $500 \mathrm{~h} \mathrm{deg-}$ radation experiment.

It shows a comparable composition to the FBS mixture presented in Table 1 and again in Table 3, besides a higher $\mathrm{N}_{2}$ concentration thus lowering the power output but not influencing WGS and MSR reactions. The higher $\mathrm{N}_{2}$ content in comparison to the FBS mixture presented in Table 1 results from pressurizing the fuel tank with $\mathrm{N}_{2}$ necessary for the operation of the in-house FBS gasifier. The steam content of $36 \mathrm{vol} \%$ in the fuel mixture used shows a risk for degradation due to nickel re-oxidation (see Eq. (5)) according to [42] which is relevant to investigate for industrial applications. Nevertheless, it is far below 50 vol\% to avoid a strong ASR increase, and therefore higher polarization losses as well as it ensures a $\mathrm{H}_{2} \mathrm{O} / \mathrm{CH}_{4}$ ratio higher than 1 .

In the experiment, the cell was fueled with a synthetic product gas with a composition derived from an in-house FBS gasifier with a steam content of $36 \mathrm{vol} \%$ presented in Table 3 . The cell was loaded with $300 \mathrm{~mA} / \mathrm{cm}^{2}$ electric load and operated at a regulated oven temperature of $800{ }^{\circ} \mathrm{C}$ for $500 \mathrm{~h}$, thus simulating a common operating point for a FBS gasifier [33]. Current-voltage curves as well as EIS-spectra were recorded every $2 \mathrm{~h}$ to track performance degradation as a result of possible nickel re-oxidation within the anode. Afterwards, SEM and EDX analyses were conducted to investigate changes in the anode structure.

Figure 14 presents the results of the electrochemical analysis, whereas the measured data at the beginning

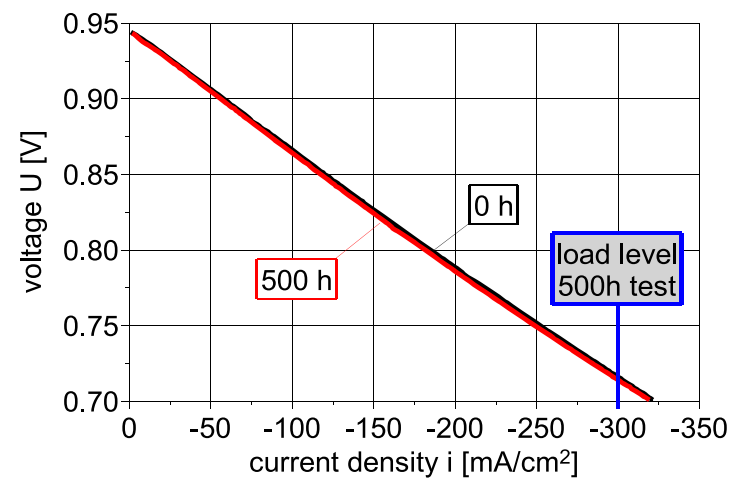

a) current voltage correlations and the end of the $500 \mathrm{~h}$ experiment are shown: The current-voltage correlation stays the same as shown in Fig. 14a. Hence, no performance degradation can be assumed. However, degradation in the cell structure resulting in higher ohmic or polarization resistances of the cell can be possible.

Therefore, the EIS spectra at $300 \mathrm{~mA} / \mathrm{cm}^{2}$ at the beginning and the end of the experiment were compared and presented in Fig. 14b. They show no changes neither in the ohmic resistance nor the polarization resistance of the cell, which explains the unchanged current-voltage correlation.

Nevertheless, performance degradation analyses based on current-voltage curves and EIS do not deliver information about possible changes in the microstructure of the anode, which could cause a fast cell degradation after yet longer periods of operation. Therefore, SEM and EDX analyses were conducted to investigate possible changes in the anodic structure. Figure 15 shows the results of these analyses.

A reduced but unloaded cell was used as reference with definitely no oxidized nickel. When comparing the SEM picture of the reduced but unloaded cell (Fig. 15b) with the picture of the cell fueled with the synthetic FBS product gas for $500 \mathrm{~h}$ (Fig. 15c), no significant differences in nickel grainsize or shape can be detected. Considering the EDX spectra, also no changes in the anode composition can be assumed as the oxygen peak representing nickel oxide (gray-colored) stays at the same size and shape. This would speak for a degradation resistance of the anode at the applied operating conditions. The different distribution of GDC on nickel grains is not argued as a result of the $500 \mathrm{~h}$ experiment but of manufacturing tolerances between the reference and tested cell. Furthermore, the SEM picture of an oxidized cell was taken into account to confirm the assumption of an unchanged anode after the $500 \mathrm{~h}$ experiment. Considering the surface of the oxidized anode in Fig. 15d, nickel grains are obviously larger, which correlates with the lower density of $\mathrm{NiO}$ in comparison to the density of Ni [11]. Moreover, most of the grain surface shows a rough structure pointing to potentially $\mathrm{NiO}$ growth on the surface of

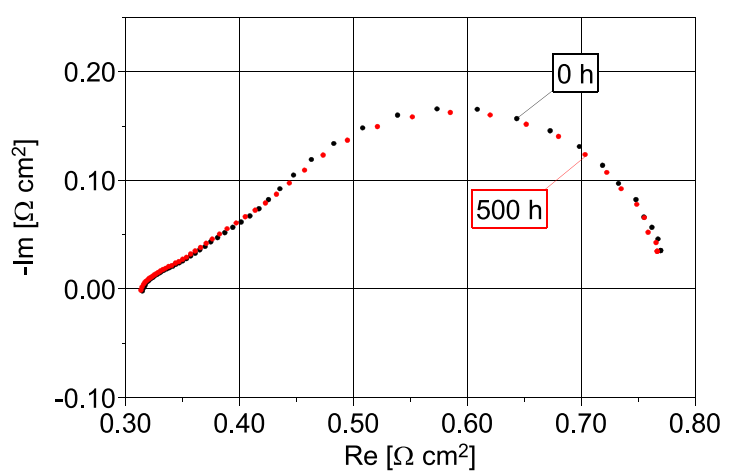

b) EIS spectra at $300 \mathrm{~mA} / \mathrm{cm}^{2}$

Fig. 14 Current-voltage-curves (a) and impedance spectra (b) of cell before and after $500 \mathrm{~h}$ stability experiment with synthetic FBS product gas containing 36 vol\% $\mathrm{H}_{2} \mathrm{O}$ 


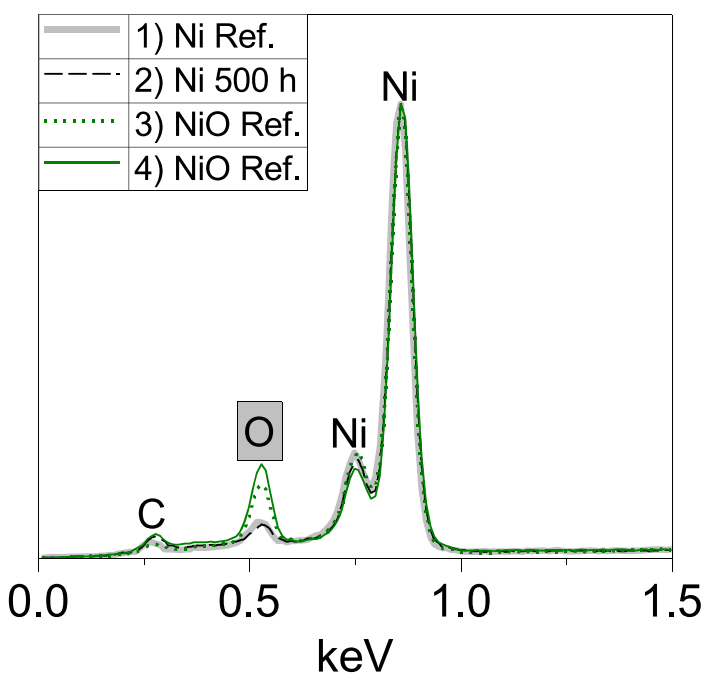

a) EDX spectra at marked surfaces

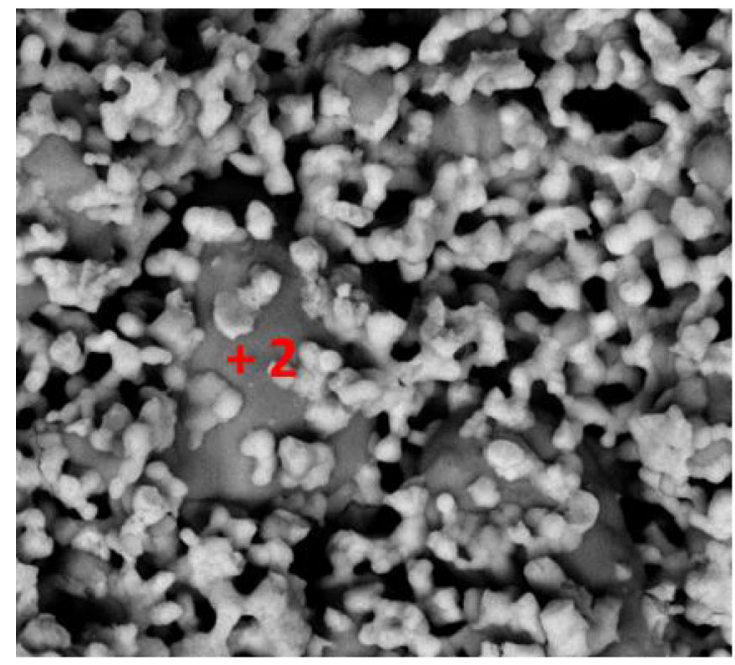

c) cell after $500 \mathrm{~h}$ experiment

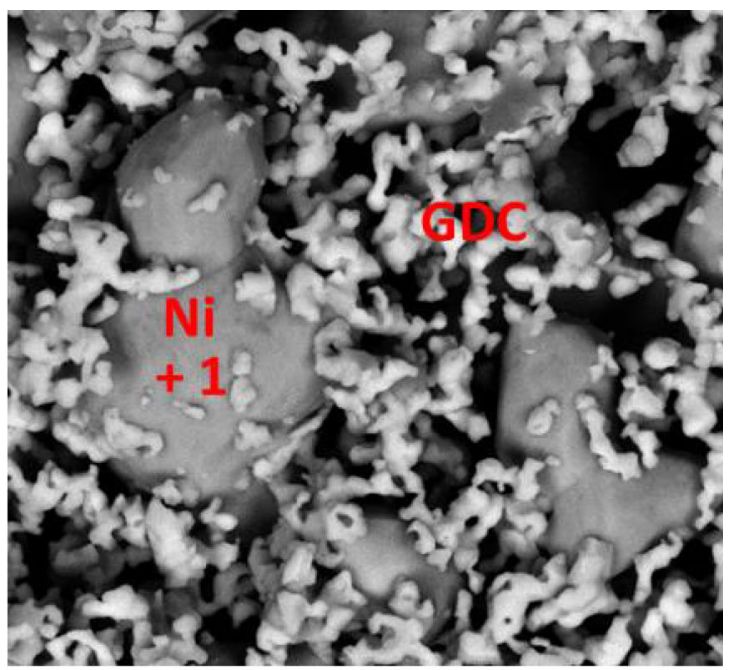

b) reduced, unloaded cell

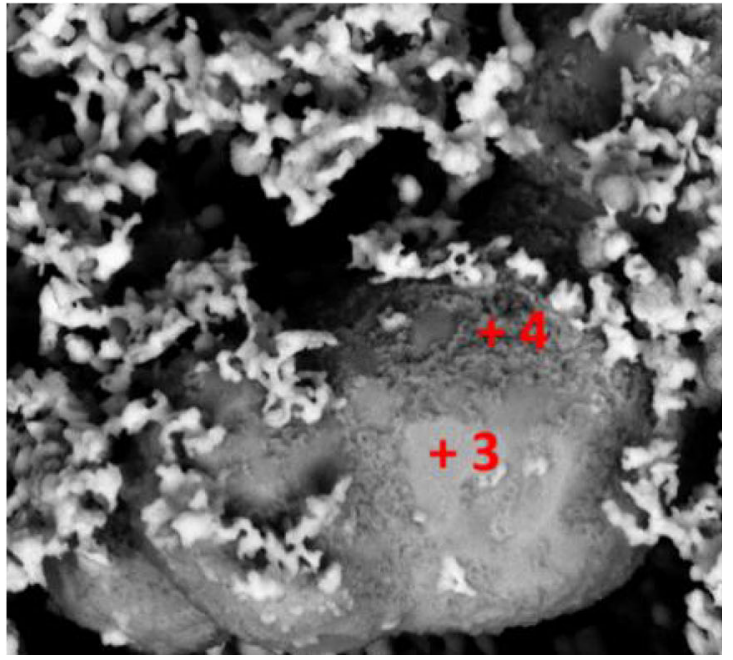

d) oxidized cell

Fig. 15 (a) EDX spectra at numbered surface marks of (b) reduced but unloaded reference cell, (c) anode after $500 \mathrm{~h}$ experiment and (d) oxidized reference cell. All SEM pictures are presented with same magnification

the grain. The different surface structures were further on investigated via EDX analyses, resulting in a high oxygen peak of the surface in point 3 and an even higher peak in point 4 , thus reassuring a non-degraded anode in Fig. 15c.

In summary, it is claimed that fueling a $\mathrm{Ni} / \mathrm{GDC}$ ESC with a synthetic FBS gasifier product gas containing 36 vol\% $\mathrm{H}_{2} \mathrm{O}$ for $500 \mathrm{~h}$ under high electric load does not result in performance or anode degradation. However, slight changes in the distribution of anode components might be possible but do not influence cell performance. Results of this experiment will be used as well for comparisons with results of future experiments with (i) contaminants added to the simulated FBS gasifier product gas and (ii) real product gases from the gasifier.

\section{Conclusions and outlook}

This work presents a comprehensive study on the influence of main gas components on the performance of an industrial-size SOFC relevant for the use with product gases from biomass gasification.

- First, ESC-SOFCs with Ni/GDC anode were claimed having the highest potential for the use with biomass gasifiers due to (i) their higher tolerance against catalyst contaminants and thus better resistivity to solid carbon deposits than cells with $\mathrm{Ni} / \mathrm{YSC}$ anode, as well as (ii) their lower risk of failure resulting from cracks in the anodic structure in comparison to ASC-SOFCs. 
- Second, changes in cell characteristics when adding carbonaceous species $\mathrm{CO}, \mathrm{CH}_{4}$ and $\mathrm{CO}_{2}$ while decreasing the $\mathrm{N}_{2}$ content of a reference gas mixture of 50/25/25 vol\% $\mathrm{H}_{2} / \mathrm{H}_{2} \mathrm{O} / \mathrm{N}_{2}$ representing biomass gasifier product gases were investigated with following key findings:

- CO: Fast load changes increase the rate of CO directly oxidized before leading to the formation of $\mathrm{H}_{2}$ via the WGS reaction. As a result, the power output stagnates despite an increasing LHV of the fuel gas, especially at low $\mathrm{H}_{2} / \mathrm{CO}$ ratios. A high $\mathrm{H}_{2} / \mathrm{CO}$ ratio should therefore be aimed for.

- $\mathrm{CH}_{4}$ : To avoid high voltage losses and ensure linearity of the current voltage correlation especially in the low load range, a $\mathrm{H}_{2} \mathrm{O} / \mathrm{CH}_{4}$ ratio higher than 1 is recommended. Moreover, even small $\mathrm{CH}_{4}$ amounts can increase the cell performance to a larger extend than high $\mathrm{CO}$ concentrations and should therefore be favored.

- $\mathrm{CO}_{2}$ : Parts of $\mathrm{CO}_{2}$ in the gas mixture react with electrochemically high-reactive $\mathrm{H}_{2}$ to form $\mathrm{CO}$ and $\mathrm{H}_{2} \mathrm{O}$ via the water gas shift reaction. Moreover, high amounts of $\mathrm{CO}_{2}$ increase the diffusion resistance for electrochemically active species. Therefore, $\mathrm{CO}_{2}$ concentrations should be aimed as low as possible in the gas mixture.

Based on these key findings, FBS gasifier product gases are claimed as most suitable for the use as SOFC fuel. Comparing current-voltage correlations of a cell fueled with a common FDA and FBS product gas clearly showed better performance for the FBS case, especially at higher load levels. However, FDA gasifiers are currently the only option in the market for small-to-medium size ranges, since in this case FBS gasifiers are more complex and not economically feasible for small scales. Using oxygen enriched steam or steam enriched air as gasification agent as well as steam injection in the product gas line of commercially realized FDA gasifiers could significantly improve suitability of fixed bed gasifier product gases for SOFCs at decreasing degradation risk.

- Third, the stability of a loaded cell fueled with a synthetic FBS gasifier product gas with high steam fraction claimed as most promising for the use with SOFCs was investigated. The cell was run for $500 \mathrm{~h}$ showing no performance degradation. Microscopic investigations proved anode stability, especially considering re-oxidation of anodic nickel. Despite doubted in literature, degradation free usage of steam-rich FBS product gases in SOFCs could be proved by the authors additionally highlighting its high potential for the use as SOFC fuel.

Experiments using real product gases from biomass gasifiers as SOFC fuel under industrial-relevant operating conditions, like higher fuel utilization and temperatures beneficial for thermal implementation in a combined heat and power (CHP) system, will be necessary in the future to bring gasifier-SOFC systems closer to commercialization.

Acknowledgments The financial support by the Austrian Ministry for Transport, Innovation and Technology (bmvit) for the BIO-CCHP project (FFG number 869036) within the framework of the 11th Joint Call of ERA-NET Bioenergy is gratefully acknowledged.

Funding information Open access funding provided by Graz University of Technology.

Abbreviations $A E R$, absorption enhanced reforming; $A S C$, anode supported cell; $A S R$, area specific resistance; $C H P$, combined heat and power; $D F B$, dual fluidized bed; $E D X$, energy-dispersive $\mathrm{X}$-ray spectroscope; $E I S$, electrochemical impedance spectroscopy; $E S C$, electrolyte supported cell; $F B S$, fluidized bed steam; $F D A$, fixed-bed downdraft air; $L H V$, lower heating value; $L S M$, lanthanum strontium manganite; $M S R$, methane steam reforming; $\mathrm{Ni} / \mathrm{GDC}$, nickel/gadolinium-doped ceria; $\mathrm{Ni} / \mathrm{YSZ}$, nickel/yttria-stabilized zirconia; $O C V$, open circuit voltage; $S C R$, steam to carbon ratio; $S E M$, scanning electron microscopy; $S O F C$, solid oxide fuel cell; SSZ, scandia stabilized zirconia; WGS, water gas shift

List of symbols $\Delta_{\mathrm{R}} \mathrm{H}_{\mathrm{m}}{ }^{0}$, molar standard enthalpy of reaction $[\mathrm{kJ} / \mathrm{mol}]$; $\Delta^{\mathrm{R}} \mathrm{G}_{\mathrm{m}}{ }^{0}$, molar standard Gibbs enthalpy of reaction $[\mathrm{kJ} / \mathrm{mol}] ; R_{\mathrm{m}}$, molar gas constant $[\mathrm{J} / \mathrm{mol}-\mathrm{K}] ; F$, Faraday constant $[\mathrm{As} / \mathrm{mol}] ; n_{\mathrm{el}}$, number of electrons; $\gamma^{\mathrm{st}}{ }_{\mathrm{i}}$, stoichiometric coefficient of component $i$; T, cell temperature [K]; U, cell voltage [V]; OCV, open circuit voltage [V]; $U_{\mathrm{f}}$, fuel utilization [\%]; $i$, cell current density $\left[\mathrm{mA} / \mathrm{cm}^{2}\right] ; \eta_{\mathrm{el}}$, electrical efficiency $[\%] ; \Delta \mathrm{U}_{\text {loss }}$, sum of voltage losses [V]; $p_{\mathrm{i}}$, partial pressure of component $i$ $\left[\mathrm{N} / \mathrm{m}^{2}\right] ; p_{0}$, standard pressure $\left[\mathrm{N} / \mathrm{m}^{2}\right] ; R_{\Omega}$, ohmic resistance cell $\left[\Omega \mathrm{cm}^{2}\right]$; $R_{\text {Pol }}$, polarization resistance cell $\left[\Omega \mathrm{cm}^{2}\right] ; \dot{V}_{\text {Anode }}$, anodic volume flow

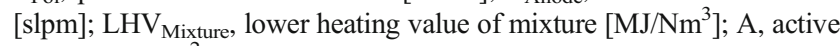
cell area in $\left[\mathrm{cm}^{2}\right] ; \dot{n}_{\text {FuelIn }}$, molar flux of fuel at inlet $[\mathrm{mol} / \mathrm{s}]$

Open Access This article is licensed under a Creative Commons Attribution 4.0 International License, which permits use, sharing, adaptation, distribution and reproduction in any medium or format, as long as you give appropriate credit to the original author(s) and the source, provide a link to the Creative Commons licence, and indicate if changes were made. The images or other third party material in this article are included in the article's Creative Commons licence, unless indicated otherwise in a credit line to the material. If material is not included in the article's Creative Commons licence and your intended use is not permitted by statutory regulation or exceeds the permitted use, you will need to obtain permission directly from the copyright holder. To view a copy of this licence, visit http://creativecommons.org/licenses/by/4.0/.

\section{References}

1. Heidenreich S, Foscolo PU (2015) New concepts in biomass gasification. Prog Energy Combust Sci 46:72-95. https://doi.org/10. 1016/j.pecs.2014.06.002

2. Pieratti E, Baratieri M, Ceschini S, Tognana L, Baggio P (2011) Syngas suitability for solid oxide fuel cells applications produced via biomass steam gasification process: experimental and modeling analysis. J Power Sources 196:10038-10049. https://doi.org/10. 1016/j.jpowsour.2011.07.090

3. Radenahmad N, Azad AT, Saghir M, Taweekun J, Bakar MSA, Reza MS, Azad AK (2020) A review on biomass derived syngas for SOFC based combined heat and power application. Renew Sust Energ Rev 119:109560. https://doi.org/10.1016/j.rser.2019.109560 
4. Ud Din Z, Zainal ZA (2017) The fate of SOFC anodes under biomass producer gas contaminants. Renew Sust Energ Rev 72:1050 1066. https://doi.org/10.1016/j.rser.2016.10.012

5. Papurello D, Chiodo V, Maisano S, Lanzini A, Santarelli M (2018) Catalytic stability of a Ni-catalyst towards biogas reforming in the presence of deactivating trace compounds. Renew Energy 127: 481-494. https://doi.org/10.1016/j.renene.2018.05.006

6. Kupecki J, Papurello D, Lanzini A, Naumovich Y, Motylinski K, Blesznowski M, Santarelli M (2018) Numerical model of planar anode supported solid oxide fuel cell fed with fuel containing $\mathrm{H} 2 \mathrm{~S}$ operated in direct internal reforming mode (DIR-SOFC). Appl Energy 230:1573-1584. https://doi.org/10.1016/j.apenergy. 2018.09.092

7. Jeong H, Geis M, Lenser C, Lobe S, Herrmann S, Fendt S, Menzler NH, Guillon O (2018) Coupling SOFCs to biomass gasification - the influence of phenol on cell degradation in simulated bio-syngas. Part II - post-test analysis. Int $\mathrm{J}$ Hydrog Energy 43:20911-20920. https://doi.org/10.1016/j. ijhydene.2018.09.006

8. Lanzini A, Ferrero D, Papurello D, Santarelli M (2017) Reporting degradation from different fuel contaminants in Ni-anode SOFCs. Fuel Cells 17:423-433. https://doi.org/10.1002/fuce.201600184

9. O'Hayre RP, Cha S-W, Colella WG, Prinz FB (2016) Fuel cell fundamentals, Third edn. John Wiley \& Sons Inc, Hoboken

10. Hanna J, Lee WY, Shi Y, Ghoniem AF (2014) Fundamentals of electro- and thermochemistry in the anode of solid-oxide fuel cells with hydrocarbon and syngas fuels. Prog Energy Combust Sci 40: 74-111. https://doi.org/10.1016/j.pecs.2013.10.001

11. Tariq F, Ruiz-Trejo E, Bertei A, Boldrin P, Brandon NP (2017) Microstructural Degradation. In: Solid Oxide Fuel Cell Lifetime and Reliability. Elsevier, pp 79-99

12. Farnak M, Esfahani JA, Bozorgmehri S (2019) An experimental investigation on flow-rate effects of internal CPOX reforming in SOFCs. Appl Therm Eng 163:114411. https://doi.org/10.1016/j. applthermaleng.2019.114411

13. Weber A, Sauer B, Müller AC, Herbstritt D, Ivers-Tiffée E (2002) Oxidation of $\mathrm{H} 2, \mathrm{CO}$ and methane in SOFCs with Ni/YSZ-cermet anodes. Solid State Ionics 152-153:543-550. https://doi.org/10. 1016/S0167-2738(02)00359-4

14. Kromp A, Leonide A, Weber A, Ivers-Tiffée E (2011) Electrochemical analysis of reformate-fuelled anode supported SOFC. J Electrochem Soc 158:B980-B986. https://doi.org/10. $1149 / 1.3597177$

15. Lebreton M, Delanoue B, Baron E, Ricoul F, Kerihuel A, Subrenat A, Joubert O, Le Gal La Salle A (2015) Effects of carbon monoxide, carbon dioxide, and methane on nickel/yttria-stabilized zirconia-based solid oxide fuel cells performance for direct coupling with a gasifier. Int J Hydrog Energy 40:10231-10241. https://doi.org/10.1016/j.ijhydene.2015.06.009

16. Matsuzaki Y, Yasuda I (2000) Electrochemical oxidation of $\mathrm{H} 2$ and $\mathrm{CO}$ in a $\mathrm{H} 2-\mathrm{H} 2 \mathrm{O}-\mathrm{CO}-\mathrm{CO} 2$ system at the interface of a NiYSZ cermet electrode and YSZ electrolyte. J Electrochem Soc 147: 1630-1635. https://doi.org/10.1149/1.1393409

17. Kupecki J, Motylinski K, Milewski J (2018) Dynamic analysis of direct internal reforming in a SOFC stack with electrolytesupported cells using a quasi-1D model. Appl Energy 227:198205. https://doi.org/10.1016/j.apenergy.2017.07.122

18. Belyaev VD, Politova TI, Mar'ina OA, Sobyanin VA (1995) Internal steam reforming of methane over Ni-based electrode in solid oxide fuel cells. Appl Catal A Gen 133:47-57. https://doi. org/10.1016/0926-860X(95)00184-0

19. Choudhary T, Sanjay (2016) Computational analysis of IR-SOFC: thermodynamic, electrochemical process and flow configuration dependency. Int J Hydrog Energy 41:1259-1271. https://doi.org/ 10.1016/j.jhydene.2015.10.098
20. Aravind PV, Ouweltjes JP, de Heer E, Woudstra N, Rietveld G (2005) Impact of biosyngas and its components on SOFC anodes. ECS Proc 2005-07:1459-1467. https://doi.org/10.1149/200507. 1459PV

21. Singhal SC, Kendall K (2003) High-temperature solid oxide fuel cells: fundamentals, design, and applicatons. Elsevier Advanced Technology, New York

22. Subotić V, Stoeckl B, Lawlor V, Strasser J, Schroettner H, Hochenauer C (2018) Towards a practical tool for online monitoring of solid oxide fuel cell operation: an experimental study and application of advanced data analysis approaches. Appl Energy 222:748-761. https://doi.org/10.1016/j.apenergy.2018.03.182

23. Jiang Y, Virkar AV (2003) Fuel composition and diluent effect on gas transport and performance of anode-supported SOFCs. J Electrochem Soc 150:A942-A951. https://doi.org/10.1149/1. 1579480

24. Motylinski K, Skrzypkiewicz M, Naumovich Y, Wierzbicki M, Kupecki J (2018) Effects of gas velocity on formation of carbon deposits on AS-SOFC fuel electrodes. J Power Technol 98:322328

25. Stoeckl B, Subotić V, Preininger M, Schroettner H, Hochenauer C (2018) SOFC operation with carbon oxides: experimental analysis of performance and degradation. Electrochim Acta 275:256-264. https://doi.org/10.1016/j.electacta.2018.04.036

26. Sumi H, Shimada H, Yamaguchi Y, Yamaguchi T, Fujishiro Y (2020) Degradation evaluation by distribution of relaxation times analysis for microtubular solid oxide fuel cells. Electrochim Acta 339:135913. https://doi.org/10.1016/j.electacta.2020.135913

27. Papurello D, Menichini D, Lanzini A (2017) Distributed relaxation times technique for the determination of fuel cell losses with an equivalent circuit model to identify physicochemical processes. Electrochim Acta 258:98-109. https://doi.org/10.1016/j.electacta. 2017.10.052

28. Baldinelli A, Barelli L, Bidini G (2015) Performance characterization and modelling of syngas-fed SOFCs (solid oxide fuel cells) varying fuel composition. Energy 90:2070-2084. https://doi.org/ 10.1016/j.energy.2015.07.126

29. Aravind PV, de Jong W (2012) Evaluation of high temperature gas cleaning options for biomass gasification product gas for solid oxide fuel cells. Prog Energy Combust Sci 38:737-764. https://doi. org/10.1016/j.pecs.2012.03.006

30. Liu M, Aravind PV (2014) The fate of tars under solid oxide fuel cell conditions: a review. Appl Therm Eng 70:687-693. https://doi. org/10.1016/j.applthermaleng.2014.05.068

31. Ihara M, Matsuda K, Sato H, Yokoyama C (2004) Solid state fuel storage and utilization through reversible carbon deposition on an SOFC anode. Solid State Ionics 175:51-54. https://doi.org/10. 1016/j.ssi.2004.09.020

32. Stoeckl B, Subotić V, Reichholf D, Schroettner H, Hochenauer C (2017) Extensive analysis of large planar SOFC: operation with humidified methane and carbon monoxide to examine carbon deposition based degradation. Electrochim Acta 256:325-336. https:// doi.org/10.1016/j.electacta.2017.09.026

33. Subotić V, Baldinelli A, Barelli L, Scharler R, Pongratz G, Hochenauer C, Anca-Couce A (2019) Applicability of the SOFC technology for coupling with biomass-gasifier systems: short- and long-term experimental study on SOFC performance and degradation behaviour. Appl Energy 256:113904. https://doi.org/10.1016/ j.apenergy.2019.113904

34. Bridgwater AV (1995) The technical and economic feasibility of biomass gasification for power generation. Fuel 74:631-653. https://doi.org/10.1016/0016-2361(95)00001-L

35. Bridgwater AV, Hofbauer H, Sjaak VL (2009) Thermal biomass conversion. CPL Press, Newbury

36. Pfeifer C, Koppatz S, Hofbauer H (2011) Steam gasification of various feedstocks at a dual fluidised bed gasifier: impacts of 
operation conditions and bed materials. Biomass Convers Biorefinery 1:39-53. https://doi.org/10.1007/s13399-011-0007-1

37. Jia J, Abudula A, Wei L, Sun B, Shi Y (2015) Thermodynamic modeling of an integrated biomass gasification and solid oxide fuel cell system. Renew Energy 81:400-410. https://doi.org/10.1016/j. renene.2015.03.030

38. Argyle M, Bartholomew C (2015) Heterogeneous catalyst deactivation and regeneration: a review. Catalysts 5:145-269. https://doi. org/10.3390/catal5010145

39. Jaworski Z, Zakrzewska B, Pianko-Oprych P (2017) On thermodynamic equilibrium of carbon deposition from gaseous C-H-O mixtures: updating for nanotubes. Rev Chem Eng 33. https://doi.org/ 10.1515/revce-2016-0022

40. Schluckner C, Subotić V, Lawlor V, Hochenauer C (2015) Carbon deposition simulation in porous SOFC anodes: a detailed numerical analysis of major carbon precursors. J Fuel Ell Sci Technol 12: 051007-051007-12. https://doi.org/10.1115/1.4031862

41. Alzate-Restrepo V, Hill JM (2008) Effect of anodic polarization on carbon deposition on Ni/YSZ anodes exposed to methane. Appl Catal A Gen 342:49-55. https://doi.org/10.1016/j.apcata.2007.12. 039

42. Hofmann P, Panopoulos KD, Fryda LE, Schweiger A, Ouweltjes JP, Karl J (2008) Integrating biomass gasification with solid oxide fuel cells: effect of real product gas tars, fluctuations and particulates on Ni-GDC anode. Int J Hydrog Energy 33:2834-2844. https://doi.org/10.1016/j.ijhydene.2008.03.020

43. Holzer L, Iwanschitz B, Hocker T, Münch B, Prestat M, Wiedenmann D, Vogt U, Holtappels P, Sfeir J, Mai A, Graule T (2011) Microstructure degradation of cermet anodes for solid oxide fuel cells: quantification of nickel grain growth in dry and in humid atmospheres. J Power Sources 196:1279-1294. https://doi.org/10. 1016/j.jpowsour.2010.08.017

44. Hansen JB, Rostrup-nielsen J, Lyngby HTA (2009) Chapter 65 sulfur poisoning on Ni catalyst and anodes. In: Handbook of fuel cells - fundamentals, technology and applications. John Wiley \& Sons Inc., New York

45. Kusnezoff M, Trofimenko N, Müller M, Michaelis A (2016) Influence of electrode design and contacting layers on performance of electrolyte supported SOFC/SOEC single cells. Materials 9:906. https://doi.org/10.3390/ma9110906
46. Trofimenko N, Kusnezoff M, Michaelis A (2017) Optimization of ESC performance for co-electrolysis operation. ECS Trans 78: 3025-3037. https://doi.org/10.1149/07801.3025ecst

47. Koch S, Hendriksen PV, Mogensen M, Liu Y-L, Dekker N, Rietveld B, de Haart B, Tietz F (2006) Solid oxide fuel cell performance under severe operating conditions. Fuel Cells 6:130-136. https://doi.org/10.1002/fuce.200500112

48. Larrain D, Van Herle J, Favrat D (2006) Simulation of SOFC stack and repeat elements including interconnect degradation and anode reoxidation risk. J Power Sources 161:392-403. https://doi.org/10. 1016/j.jpowsour.2006.04.151

49. Janssen A, Rietveld B, Vinke I, Kiviaho J G De Marco, A Pilenga, M. Honselaar, T Malkow (n.d.) G Tsotridis European Commission, Joint Research Centre, Institute for Energy, Petten. 38

50. Klotz D (2012) Characterization and modeling of electrochemical energy conversion systems by impedance techniques

51. Stoeckl B, Subotić V, Preininger M, Schwaiger M, Evic N, Schroettner H, Hochenauer C (2019) Characterization and performance evaluation of ammonia as fuel for solid oxide fuel cells with Ni/YSZ anodes. Electrochim Acta 298:874-883. https://doi.org/10. 1016/j.electacta.2018.12.065

52. Schluckner C, Subotić V, Lawlor V, Hochenauer C (2016) Numerical SOFC anode catalyst occupation study: internal reforming of carbonaceous fuel mixtures. J Electrochem Soc 163: F761-F770. https://doi.org/10.1149/2.0061608jes

53. Reid RC, Prausnitz JM, Poling BE (1987) The properties of gases \& liquids

54. Kaltschmitt M, Hartmann H, Hofbauer H (2016) Energie aus Biomasse: Grundlagen, Techniken und Verfahren, 3., aktualisierte und erweiterte Auflage. Springer Vieweg, Berlin

55. Emami Taba L, Irfan MF, Wan Daud WAM, Chakrabarti MH (2012) The effect of temperature on various parameters in coal, biomass and CO-gasification: a review. Renew Sust Energ Rev 16:5584-5596. https://doi.org/10.1016/j.rser.2012.06.015

Publisher's note Springer Nature remains neutral with regard to jurisdictional claims in published maps and institutional affiliations. 